UNIVERSIDADE DE BRASÍLIA - UNB

FACULDADE DE ECONOMIA, ADMINISTRAÇÃ̃, CONTABILIDADE E CIÊNCIA DA INFORMAÇÃO E DOCUMENTAÇÃO - FACE

LUIZ CARLOS BASBAUM

\title{
A INFLUÊNCIA DAS VINCULAÇÕES DE RECEITAS NO ENDIVIDAMENTO DA UNIÃO
}

Brasília - DF

2009 
LUIZ CARLOS BASBAUM

\title{
A INFLUÊNCIA DAS VINCULAÇÕES DE RECEITAS NO ENDIVIDAMENTO DA UNIÃO
}

\begin{abstract}
Monografia apresentada no curso de Especialização em Orçamento e Finanças Públicas do Programa de Pós-Graduação em Administração (PPGA) da Faculdade de Economia, Administração, Contabilidade e Ciência da Informação e Documentação (FACE), da Universidade de Brasília, como requisito parcial à obtenção do grau de Especialista em Orçamento e Finanças.
\end{abstract}

Orientador: Prof. Otavio Ladeira de Medeiros

\section{Brasília-DF}


LUIZ CARLOS BASBAUM

\section{A INFLUÊNCIA DAS VINCULAÇÕES DE RECEITAS NO ENDIVIDAMENTO DA UNIÃO}

Monografia apresentada no curso de Especialização em Orçamento e Finanças Públicas do Programa de PósGraduação em Administração (PPGA)

Prof ${ }^{\circ}$ Otávio Ladeira de Medeiros

STN - Ministério da Fazenda

Orientador 
Aos meus filhos Arthur e Thomaz

que, aqui nasceram, cresceram e aqui continuam ensinando-me, sempre. 


\section{AGRADECIMENTOS}

Ao Prof. Otávio Ladeira de Medeiros, por seu comprometimento, dedicação e principalmente por acreditar neste estudo e motivá-lo até que assumisse sua forma final.

Ao Prof. Paulo Henrique Feijó, que gentilmente contribui com sugestões na elaboração e desenvolvimento deste tema.

A todos os professores do curso de Especialização em Orçamento e Finanças Públicas do Programa de Pós-Graduação em Administração (PPGA) por ensinamentos e orientações que muito ajudaram no desenvolvimento desse trabalho.

Aos inseparáveis colegas de curso Armando Melo e Santos, Luiz Gonzaga Costa e Silvia Vetorazzo, pelas estimulantes discussões e pelo companheirismo, em especial nos momentos de maiores dificuldades por que passamos ao longo dessa jornada.

Ao amigo do Serpro, Jorge Luis Calderón, pela colaboração sem a qual não teria conseguido criar os gráficos deste trabalho.

Ao estimado amigo, Gerson Antunes, pela colaboração na confecção deste estudo e especialmente por sua paciência de revisá-lo. 
"A ação pode não trazer felicidade.

Mas não existe felicidade sem ação." Benjamin Disraeli

Político e Estadista Inglês (1804-1881) 


\section{RESUMO}

Este estudo investiga o expressivo crescimento das receitas vinculadas, especialmente a partir da Constituição de 1988 , que desde então têm mantido a sua participação em torno de $75 \%$ do total das receitas federais. Com base em literatura científica pertinente ao tema, são apresentadas e discutidas algumas idéias sobre como as receitas vinculadas e as despesas obrigatórias influenciam o endividamento da União. Inicialmente descreve-se como este grande volume de receitas vinculadas provocou uma maior rigidez no orçamento, na medida em que estas não podem ser utilizadas para financiar despesas diferentes daquelas para as quais foram criadas, conforme determina a Lei de Responsabilidade Fiscal (LRF). Também descreve-se as vantagens e inconvenientes da utilização da vinculação de receitas no orçamento, inclusive com referências a teoria tradicional. Depois comenta-se como o contingenciamento do orçamento, a expansão das contribuições e as desvinculações das receitas são instrumentos de política fiscal utilizados para tentar diluir o efeitos negativos desse engessamento do orçamento. Observa-se também que nem o contigenciamento de recursos, tampouco a criação da Desvinculação de Recursos da União (DRU) conseguiram reduzir significativamente o excessivo grau de vinculações de receitas do Governo Federal. A estratégia de expandir as Contribuições Socias, para não repartí-las com estados e municípios, só seria válida se o governo priorizasse a redução da divida pública para patamares que permitissem ao setor público desenvolver uma flexibilidade na capacidade de poupar. Conclui-se que reduzir as alíquotas das vinculações ou estancar o crescimento das despesas obrigatórias seriam interessantes sugestões para impedir-se o crescimento das receitas vinculadas. Outra sugestão seria alterar o atual modelo orçamentário de elaboração do PPA ou da LOA para o modelo do orçamento deslizante, onde utiliza-se percentuais variáveis para as vinculações de receita. De tal maneira que possibilitaria a autoridade fiscal eliminar o contingenciamento e a $\mathrm{DRU}$, além de abrir espaço para a redução da carga tributária e expansão do investimento público. Tudo isto posto, se estaria assegurando importantes ganhos a credibilidade internacional do país.

Palavras-chave: Receitas Vinculadas - Despesas Obrigatórias - Contingenciamento - Contribuição Social 


\section{LISTA DE FIGURAS}

Gráfico 1 - Composição das Receitas Orçamentárias .......................................................... 15

Gráfico 2 - Receitas Vinculadas por Área ....................................................................... 16

Gráfico 3 - Composição das Receitas Primárias Vinculadas do Governo Central (\%) ............17

Gráfico 4 - Evolução das Despesas Primárias - Empenho Liquidado (R\$ milhões) .................18

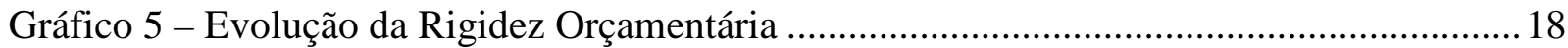

Gráfico 6 - Evolução dos Principais Impostos versus Contribuições Sociais ............................27

Gráfico 7 - Elevação da Carga Tributária ................................................................................29 


\section{LISTA DE TABELAS}

Tabela 1 - Despesas Primárias Liquidadas no Orçamento Fiscal e Seguridade em 2006................ 13

Tabela 2 - Fontes de Receita 100\% Vinculada; valores arrecadados, liquidados e pagos (2006) ...20

Tabela 3 - Recursos da DRU Liberados para o Orçamento Fiscal ................................................... 32 


\section{LISTA DE SIGLAS E ABREVIATURAS}

CIDE

COFINS

CPMF

CSLL

DRU

FEF

FSE

FUNDEF

IR

LDO

LOA

LOAS

LRF

MF

MPOG

PIB

PPA

SRF

STN
Contribuição de Intervenção no Domínio Econômico

Contribuição para o Financiamento da Seguridade Social

Contribuição Provisória sobre a Movimentação Financeira

Contribuição Social sobre o Lucro Líquido

Desvinculação das Receitas da União

Fundo de Estabilização Fiscal

Fundo Social de Emergência

Fundo de Combate à Pobreza

Imposto de Renda

Lei de Diretrizes Orçamentária

Lei Orçamentária Anual

Lei Orgânica da Assistência Social,

Lei de Responsabilidade Fiscal

Ministério da Fazenda

Ministério do Planejamento Orçamento e Gestão

Produto Interno Bruto

Plano Plurianual

Secretaria da Receita Federal

Secretaria do Tesouro Nacional 


\section{SUMÁRIO}

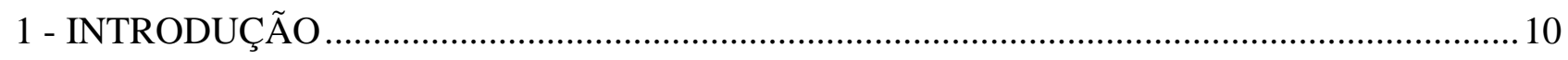

2 - CONTEXTUALIZAÇÃO DO PROBLEMA DAS VINCULAÇÕES DE RECEITAS ................12

2.1 - O orçamento e as vinculações de receita .............................................................................. 12

2.2 - Vantagens e desvantagens da vinculação de receitas ..........................................................22

3 - EVOLUÇÕES E SOLUÇÕES DO PROBLEMA AO LONGO DO TEMPO.................................23

3.1 - O contigenciamento e a política fiscal superavitária ……………………………………......23

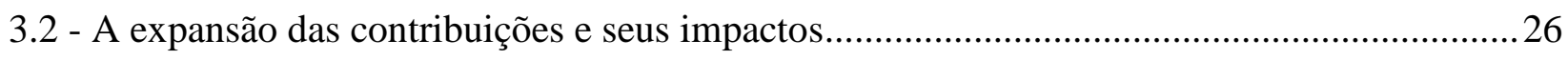

3.3 - Um mecanismo para lidar com o excesso de vinculação de receitas - criação da DRU ........31

4 - CONCLUSÃO

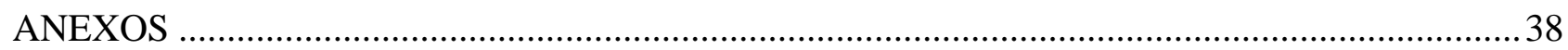

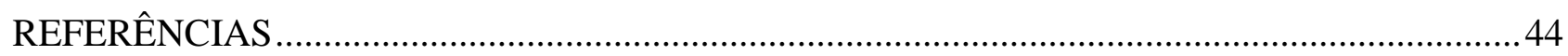




\section{Introdução}

Este estudo pretende analisar a influência das vinculações de receitas no endividamento bruto da União, discutir como o excesso de receitas vinculadas afeta o superávit primário e qual o seu impacto na administração de caixa do Governo Federal. Se propõe a discutir a influência das vinculações de receitas e outras fontes de rigidez orçamentária neste endividamento e seus efeitos, inclusive sobre o bem-estar social como complemento da implementação de uma política fiscal eficaz, política essa, extremamente prejudicada pelo contínuo aumento das vinculações de receitas. Com a atual crise econômica mundial, ainda é mais relevante discutir-se como a execução de uma eficaz política fiscal pode ser um instrumento de estímulo à geração de emprego e à redução dos efeitos negativos deste período de baixo crescimento econômico que se aproxima.

Inicialmente, com a Constituição Federal de 1988, o orçamento brasileiro passou por um processo de expressiva redução no grau de discricionariedade alocativa dos recursos. Esta redução é afetada tanto pelo excessivo grau de vinculação de receitas quanto pelo elevado nível de despesas constitucional e legalmente obrigatórias. Isto resultou num aumento na descentralização de recursos antes pertencentes ao governo federal, ou seja, diminuindo seu poder de flexibilizar a alocação de recursos de forma a permitir a execução uma política fiscal mais eficiente. Além disso, o sistema político brasileiro da Constituição de 1988 caracterizou-se pela grande dificuldade de formar maiorias no Congresso e pelos incentivos eleitorais à expansão dos gastos correntes. Como resultado, tem-se um processo decisório focado no curto-prazo, cujos principais objetivos são o equilíbrio fiscal e o atendimento da base de apoio do governo no Congresso. O planejamento e a qualidade do gasto ficam em segundo plano (MENDES, 2008).

A influência das vinculações de receita no endividamento da União tem sido discutida em alguns textos no âmbito de instituições federais, tais como; Senado Federal, Câmara Federal, Ministério do Planejamento, Secretaria do Tesouro Nacional (STN), Banco Central, etc. Porém poucos artigos científicos, como (MORA, 2005), (PIRES, 2006) e (GOLDFAJN, 2002) ou dissertações acadêmicas, como (AZEVEDO, 2006) e (PIRES JÚNIOR, 2008) tem sido escritos sobre este assunto. Algumas referências literárias preocupam-se somente em definir o significado de 'receita vinculada' ou 'cálculo do resultado primário' ou ainda 'dívida do setor público', sem entretanto fazer qualquer conexão entre esses assuntos ou tão pouco analisar como os mesmos se interligam. Outros autores chegam a sugerir a redução das vinculações e despesas obrigatórias (MORA, 2005), ou ainda a diminuição das restrições derivadas da excessiva vinculação de receitas 
a despesas específicas do orçamento (SUZUKI JÚNIOR, 2003), sem fazer contudo nenhum relacionamento entre receitas vinculadas, cálculo de resultado primário e política fiscal.

Este estudo pretende mostrar não somente como esses assuntos estão interligados, mas principalmente como o crescimento da vinculação de receita afeta o cálculo do resultado primário, seu impacto na Dívida Líquida e na Dívida Bruta do setor público e finalmente algumas sugestões para tentarmos diminuir esse impacto no endividamento bruto da União.

A fim de tentar alcançar o objetivo proposto neste trabalho será feita uma pesquisa qualitativa e documental, baseada em material científico disponível em livros, revistas especializadas e impressas em meios eletrônicos. O seu foco se baseará em material científico e informações correspondentes aos exercícios orçamentários e financeiros de 1988 a 2006.

Esse trabalho está estruturado com uma primeira parte, introdutória, onde é contextualizado o problema, são descritas as justificativas e explicados os objetivos propostos para o estudo. A segunda parte é destinada ao desenvolvimento e construção do problema, onde se analisa o processo histórico que contribuiu para a ampliação destas vinculações e mais detalhadamente, suas vantagens e inconvenientes.

A terceira parte é onde se apresenta a evolução e as alternativas ao problema ao longo do tempo. Ainda, faz-se uma breve discussão teórica dos instrumentos propostos e suas respectivas influências políticas, assim como os mecanismos para lidar com elas em um ambiente de estabilidade de preços e disciplina fiscal. A quarta parte compõe-se da conclusão deste estudo e onde se elabora algumas sugestões e observações de aprimoramento do processo orçamentário e da execução do gasto, ainda regido por antigas leis de 40 anos, à luz, inclusive do avanço institucional determinado pela LRF e outros mecanismos introduzidos depois da constituição de 1988.

Em anexo são apresentados os principais mecanismos de vinculação definidos pela Constituição de 1988 ou por emendas constitucionais com as diversas vinculações de receitas hoje existentes, a legislação que as ampara, as regras que as regem e os valores percentuais que lhes foram associados nos últimos exercícios. Também estão incluídos alguns quadros demonstrativos das vinculações de receitas antes e após a DRU. 


\section{Contextualização e desenvolvimento do problema das vinculações de receitas}

Pode-se definir receita vinculada como a receita arrecadada com destinação especifica préestabelecida pela legislação vigente. Se por um lado, esta receita vinculada pode ser um instrumento de garantia de recursos à execução do planejamento, por outro, o aumento desta vinculação introduz uma maior rigidez na programação orçamentária (STN, 2009, a). Em outras palavras pode-se dizer que receita vinculada é a receita proveniente de tributo ou contribuição, cujos valores arrecadados são direcionados, por lei ou pela Constituição, a uma determinada despesa.

\subsection{O orçamento e as vinculações de receita}

Desde a promulgação da Constituição Federal de 1988, o orçamento brasileiro vive cada vez mais num regime fiscal baseado na expansão da despesa. Isto, em parte, porque o poder Executivo tenta conciliar a priorização do equilíbrio fiscal com a execução do máximo das preferências de gastos dos parlamentares e ministros da base de apoio, como forma de manter a maioria no parlamento que lhe garanta uma governabilidade duradoura. De tal forma, que o atual sistema político acaba por priorizar a LOA de forma exagerada, a tal ponto, que se cabe chamar a atenção para os seguintes aspectos:

. Os bônus e ônus eleitorais da estabilidade fiscal e conseqüente estabilidade de preços recaem sobre o Presidente da República e os ministros da área econômica, sendo menor, ou inexistente, a preocupação dos parlamentares e demais ministros com o equilíbrio fiscal.

. Há uma significativa fragmentação de interesses político-eleitorais no Legislativo, fazendo com que as decisões orçamentárias emanadas desse poder representem a soma de interesses individuais dos parlamentares e dos ministros da base aliada do governo. Interesses estes, que se concentram no atendimento de bases eleitorais e grupos de interesse mediante expansão da despesa e onde a qualidade do gasto e a avaliação da relação custo-benefício não é uma prioridade.

- A dificuldade enfrentada pelo Poder Executivo para formar maiorias no Legislativo transforma a execução das dotações orçamentárias em moeda de troca na compra de apoio aos projetos do Executivo (MENDES, 2008).

Através dos dados da Tabela 1 pode-se fazer uma reflexão sobre o chamado "orçamento obrigatório ou mandatório”. Percebe-se ali que $92 \%$ do orçamento já é de execução obrigatória. A disputa acerca do tema "orçamento obrigatório" é em torno dos 8\% restantes (despesas 
discricionárias), onde estão incluídas as emendas parlamentares. Embora, em termos percentuais, seja uma cifra pequena, em termos absolutos estamos falando de mais de R 40 bilhões. Supondo que metade desse valor seja gasto com despesas de custeio da máquina pública, restam outros R \$ 20 bilhões, que são objeto da cobiça das diversas forças políticas. Esse montante é altamente relevante do ponto de vista do equilíbrio fiscal. Basta lembrar que o resultado primário do Governo Central em 2006 foi de $\mathrm{R}$ \$9,8 bilhões. Ou seja, o valor em disputa (cerca de R 20 bilhões) equivale a $40 \%$ do superávit primário.

Tabela 1 - Despesas Primárias Liquidadas no Orçamento Fiscal e Seguridade em 2006

\begin{tabular}{|c|c|c|}
\hline & $\mathrm{R} \$$ bilhões & $\begin{array}{c}\% \text { da } \\
\text { Despesa } \\
\text { Total }\end{array}$ \\
\hline DESPESAS OBRIGATÓRIAS (A) & 359,7 & 72 \\
\hline Benefícios Previdenciários & 161,7 & 32 \\
\hline Transf. Obrigatórias a Estados e Municípios & 97,1 & 19 \\
\hline Saúde & 39,6 & 8 \\
\hline Poderes Autônomos & 27,0 & 5 \\
\hline Abono Salarial e Seguro Desemprego & 14,9 & 3 \\
\hline LOAS e RMV & 11,6 & 2 \\
\hline Sentenças e Acordos Judiciais & 7,8 & 2 \\
\hline DESPESAS QUASE-OBRIGATÓRIAS (B) & 96,0 & 19 \\
\hline Pessoal, Enc. Sociais e Auxílio Financeiro Obrigatório a Servidores & 81,2 & 16 \\
\hline Bolsa Família & 7,6 & 2 \\
\hline Subsídios e Apoio à Agricultura & 4,6 & 1 \\
\hline FNDE e FUNDEF-Complementação & 2,5 & 1 \\
\hline OUTRAS DESP. OBRIG. OU QUASE-OBRIGATÓRIAS (C) & 1,3 & 0 \\
\hline TOTAL DE OBRIGATÓRIAS E QUASE-OBRIGATÓRIAS $(D)=(A)+(B)+(C)$ & 457,0 & 92 \\
\hline DESPESA DISCRICIONÁRIA (E) & 41,5 & 8 \\
\hline DESPESA PRIMÁRIA TOTAL (F) = (D)+(E) & 498,5 & 100 \\
\hline
\end{tabular}

Fonte: Senado Federal, Sistema Siga Brasil

Esses dados ajudam, também, a resolver outro enigma: se todos dizem que o orçamento é uma "peça de ficção", por que há tanta disputa para influenciar a sua confecção? A idéia de que o orçamento é fictício vem, justamente, da possibilidade de o Poder Executivo alterar as suas determinações mediante contingenciamento de verbas, pois ele é autorizativo e não obrigatório e impositivo. Contudo, além da constatação acima de que $92 \%$ do orçamento é de execução obrigatória, portanto não fictício, é preciso considerar que a inclusão de uma emenda no orçamento é condição necessária, porém não suficiente para que a despesa desejada seja realizada. Embora o parlamentar ou ministro não tenha certeza quanto à efetiva execução de uma despesa de seu 
interesse incluída no orçamento, ele deve lutar para que a despesa lá esteja, de forma que ela possa ser executada, pois não há possibilidade de se executar uma despesa que esteja fora do orçamento.

A Constituição também proporcionou uma forte descentralização de recursos orçamentários, através do aumento das transferências obrigatórias para estados e municípios, contudo sem ter a contrapartida dos mesmos para a execução de suas correspondentes despesas (MORA, 2005).

Em sequiência e em decorrência dos crescentes gastos implícitos na universalização do acesso às políticas sociais previstas na Constituição de 1988, criaram-se mecanismos para tornar compulsório o financiamento de políticas públicas específicas. Buscava-se, assim, proteger os gastos sociais face à restrição orçamentária intrínseca à gestão pública. E neste jogo de pressões, diversos setores da sociedade utilizaram-se de grupos políticos para conseguirem vincular as receitas de alguns tributos e contribuições, a despesas de seus interesses (educação, cinema, esportes, políticas de amparo ao trabalhador, manutenção de órgãos públicos, etc.). Contudo, essa política conduziu a um elevado percentual de vinculações e despesas obrigatórias, que engessaram o orçamento e reduziram o grau de manobra das autoridades competentes (MORA, 2005). O resultado foi um orçamento rígido, previamente alocado por determinações constitucionais e legais e com despesas crescentes.

$\mathrm{Na}$ Constituinte e ao longo dos anos seguintes expandiu-se, também, a fixação de despesas obrigatórias em algumas áreas (saúde, previdência e assistência social, judiciário, legislativo e Ministério Público). Lembrando-se que despesas obrigatórias são aquelas que a União é obrigada a fazer por determinação da Constituição ou de leis, e que não podem ser contingenciadas.

A vinculação das receitas de alguns tributos e contribuições sociais a despesas préestabelecidas, juntamente com a fixação de despesas obrigatórias em algumas áreas, acabam por resultar numa significativa redução dos recursos disponíveis para livre alocação (MENDES, 2008). Sem se esquecer que a análise desta livre alocação de recursos orçamentários é de grande importância para se avaliar a capacidade do poder público de intervir na economia, ou seja, vai indicar quais os instrumentos de política fiscal serão os mais eficazes. Isto posto, pode-se concluir que esta flexibilidade é diretamente afetada pelo excessivo grau de vinculação de receitas e pelo elevado nível de despesas constitucional e legalmente obrigatórias que reduzem esta flexibilidade alocativa da política fiscal para atender outras demandas da sociedade. Ou, ainda como diz o trabalho (BRASIL, 2003), "verifica-se que o grau de vinculação existente nos orçamentos fiscal e da seguridade social do governo federal evidencia a pequena margem que possuem os gestores 
públicos para a tomada de decisões sobre a alocação de recursos orçamentários", decisões estas que estão diretamente associadas à execução de uma política fiscal mais eficiente possível.

Pelo gráfico 1 observa-se que houve um expressivo decréscimo no percentual de receitas desvinculadas, em especial no período entre 1988 e 1994.

\section{Gráfico 1 - Composição das Receitas Orçamentárias}

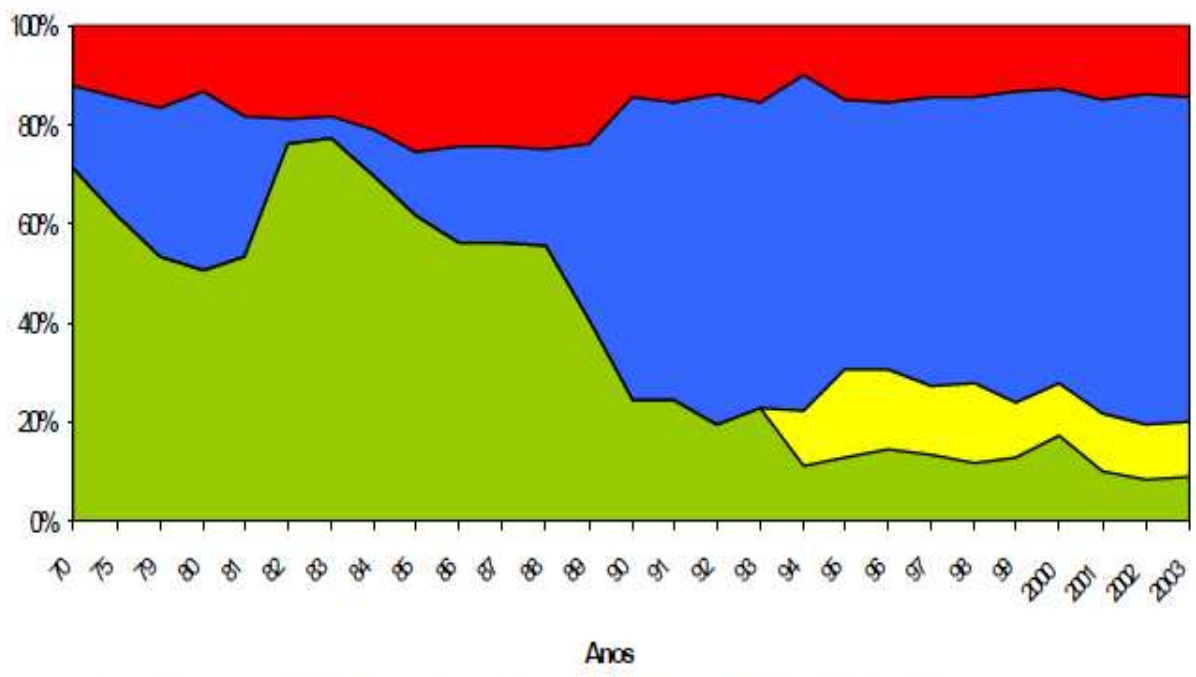

Obs: 1 - Somente receitas do Tesouro, desconsideradas as de cobcação de thus e de privatizações.

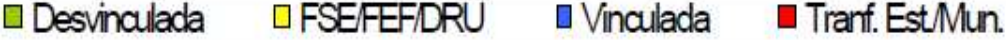

Fonte: Brasil, 2003, p.6

A tal ponto de verificar-se que:

Em 1988, os recursos da União de livre alocação representavam 55,5\% do total das receitas do Tesouro, enquanto que, em 1993, a participação caiu para 22,9\%. No exercício de 2002, considerando-se a parcela da DRU, apenas 19,4\% dos recursos da União eram isentos de vinculação, e a previsão para 2003 é que este percentual seja de 19,7\%.(BRASIL, 2003, p. 7).

No Quadro A1 do anexo que acompanha este trabalho, são apresentados os principais mecanismos de vinculação. Como se pode constatar, esses mecanismos foram definidos pela Constituição de 1988 ou por emendas constitucionais após a Constituição de 1988.

Desta forma, pode-se destacar que entre as principais vinculações criadas pela Constituição Federal de 1988, temos: 
- os recursos à educação, conforme art. 212, o qual determina que no mínimo $18 \%$ das receitas dos impostos sejam destinados à manutenção e ao desenvolvimento do ensino;

- as contribuições sociais elencadas no art. 195, as quais são vinculadas ao financiamento do orçamento da seguridade social e

- os recursos aos Estados e Municípios, por intermédio de transferências automáticas de receitas;

No que diz respeito às vinculações criadas após a Constituição de 88 , ainda pode-se destacar:

- a Contribuição Provisória sobre a Movimentação Financeira (CPMF)

- a Contribuição de Intervenção no Domínio Econômico (CIDE) sobre os Combustíveis.

O resultado de todo esse processo foi o aumento expressivo de vinculações de recursos que, a partir de 1990, têm-se mantido a sua participação em torno de $75 \%$ do total das receitas federais.

Através de uma análise na destinação destes recursos vinculados, pode-se perceber sua conseqüência no aumento da participação das contribuições no total da arrecadação da União, conforme o gráfico 2 a seguir:

\section{Gráfico 2 - Receitas Vinculadas por Área}

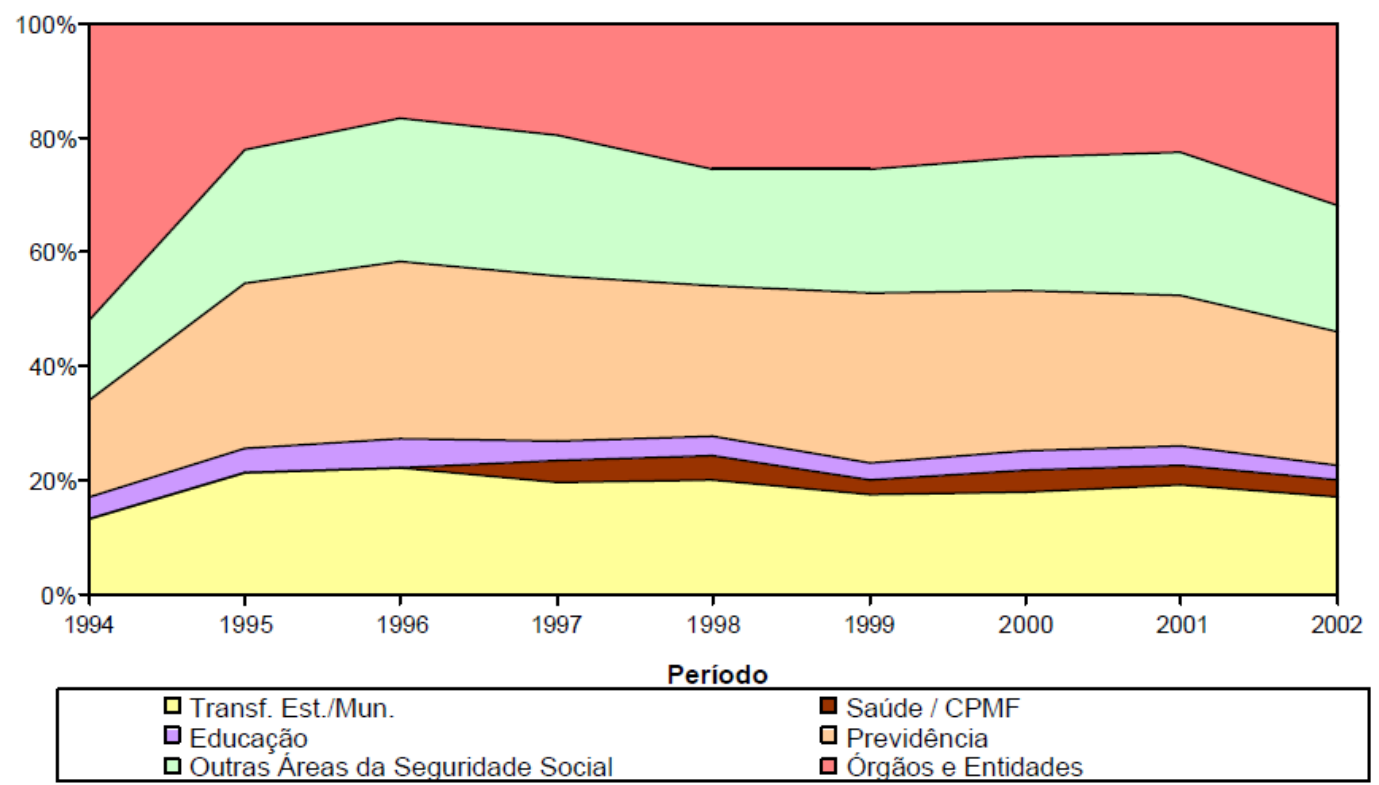

Fonte: Brasil, 2003 
Também se observa que, a partir de 1995, houve expressivo aumento da participação das receitas vinculadas à Seguridade Social (o que inclui Saúde, Previdência e outras áreas da Seguridade), em detrimento dos demais órgãos e entidades beneficiárias de recursos vinculados e das transferências para estados, DF e municípios. Em termos percentuais, a parte da Seguridade nesse total aumentou de 31,1\%, em 1994, para 46,2\%, em 2002 (MENDES, 2008). Isso se deve, em parte, às Contribuições Sociais vinculadas constitucionalmente à Seguridade Social, que apresentaram um significativo crescimento a partir de 1994. Além desse aumento da arrecadação vinculada, houve também crescimento significativo das despesas obrigatórias como a Previdência Social, Pessoal, Assistência Social e Saúde.

Podem-se classificar as vinculações de receitas entre Transferências Constitucionais, Vinculações Constitucionais à Seguridade Social, Vinculação Constitucional à Manutenção e Desenvolvimento do Ensino, Vinculações Legais a Órgãos e Fundos e Demais Vinculações Constitucionais e Legais, conforme demonstrado no Gráfico 3, que utiliza como referência o exercício de 2004.

\section{Gráfico 3 - Composição das Receitas Primárias Vinculadas do Governo Central (\%)}

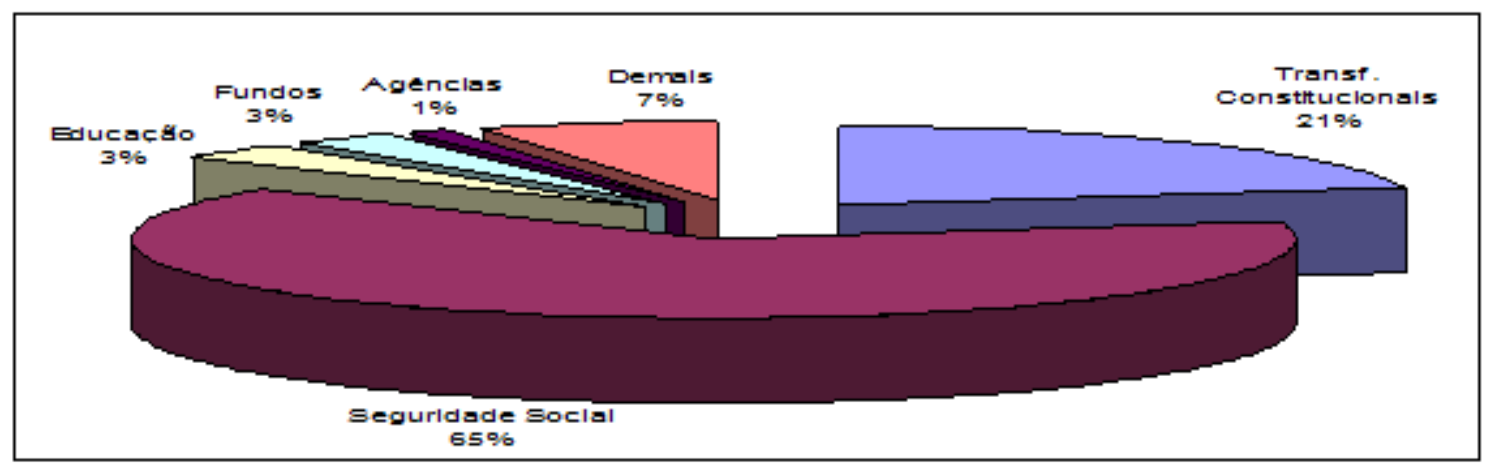

Fonte: MF/STN, 2004

O aumento contínuo do montante das despesas de execução obrigatória é um outro importante fator responsável pela redução do poder decisório do gestor público. A partir da análise da evolução no processo alocativo das despesas, constata-se que, de 1999 em diante, houve significativo acréscimo da participação dos gastos com a Previdência e com outros programas da área social em relação ao montante total, conforme o gráfico 4. 


\section{Gráfico 4 - Evolução das Despesas Primárias - Empenho Liquidado (R\$ milhões)}

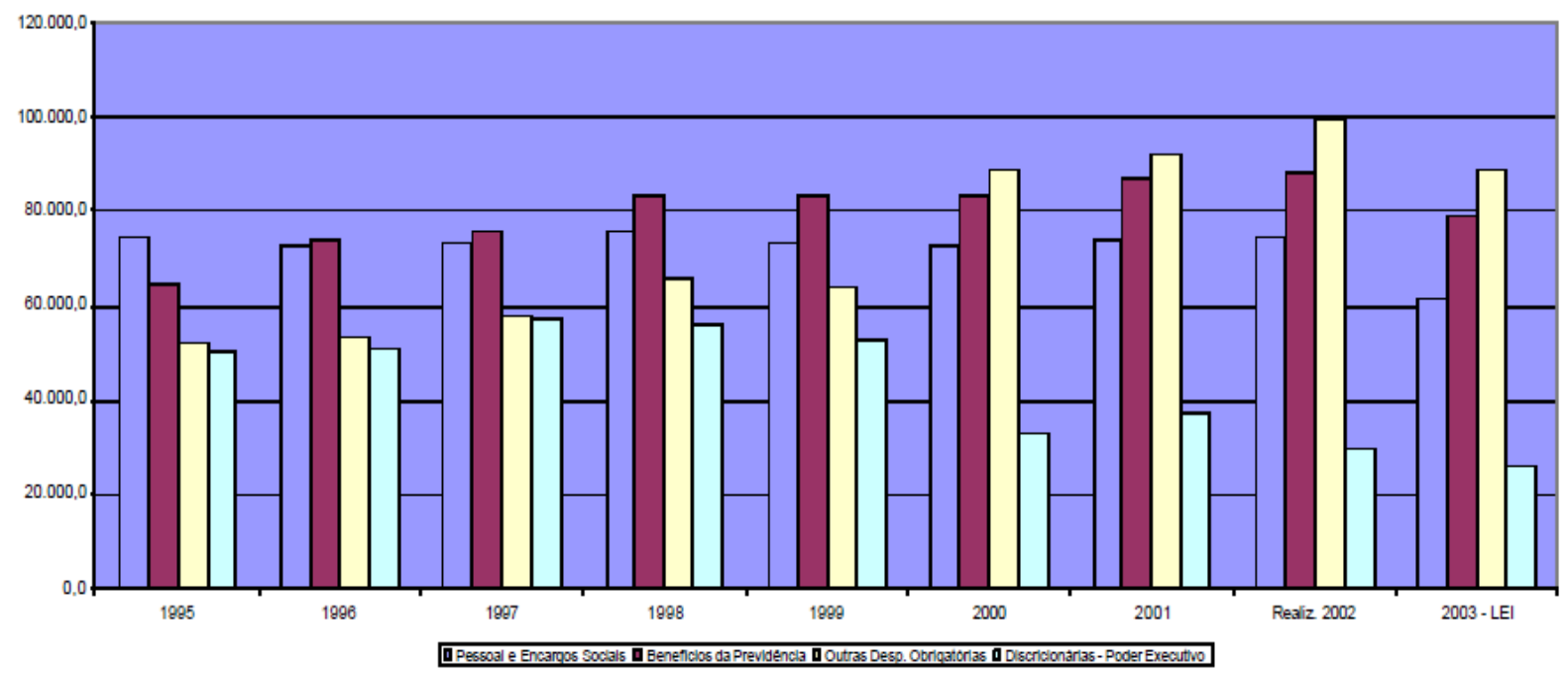

Fonte: Brasil, 2003, p.12

Assim, uma parcela de 55\% de receitas desvinculadas é destinada ao custeio de despesas de execução obrigatória, dificultando sobremaneira o gerenciamento e a condução de uma política fiscal voltada para o enfrentamento de problemas conjunturais. Ademais, a política de manutenção de um pré-determinado patamar de superávit primário reduz ainda mais o nível de despesas discricionárias do Governo, como pode ser observado no gráfico 5.

\section{Gráfico 5 - Evolução da Rigidez Orçamentária}

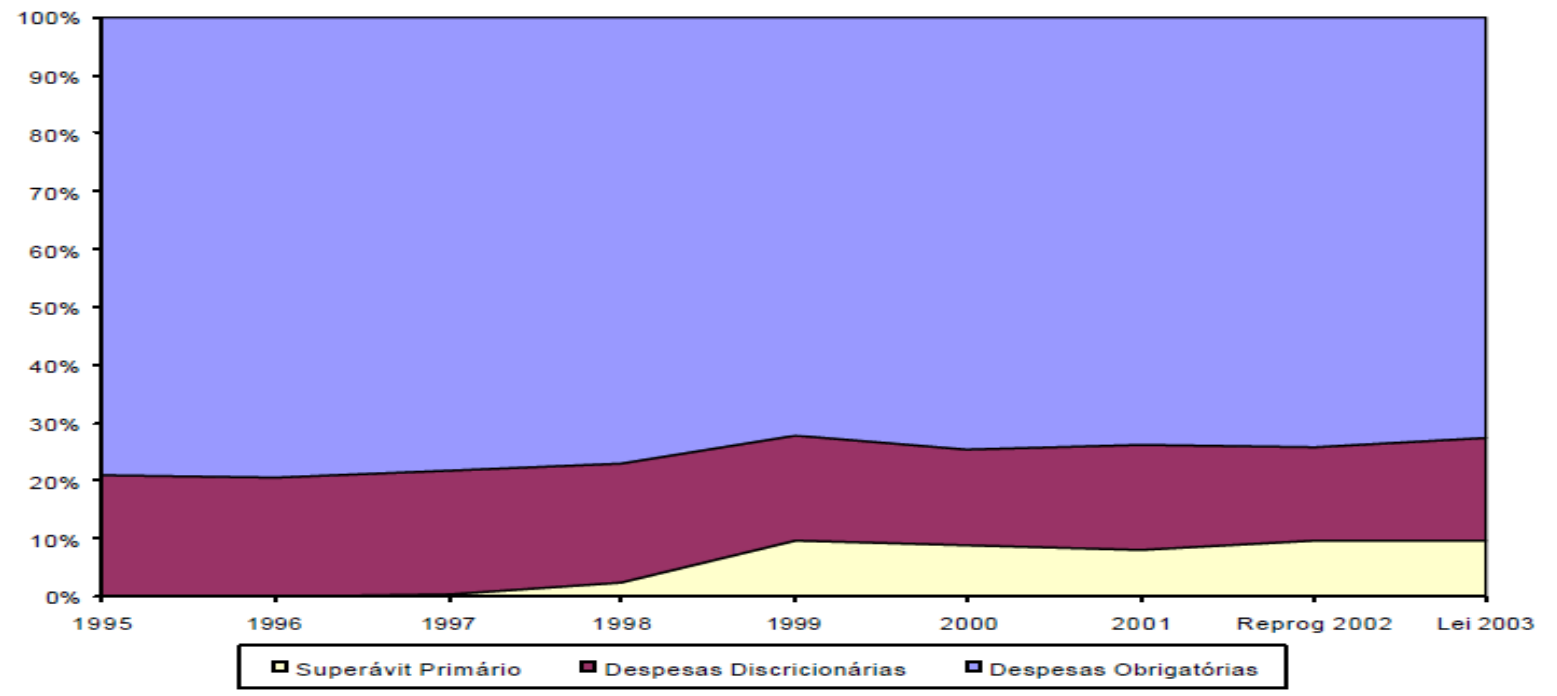

Fonte: Brasil, 2003, p.12 
Os principais fatores que contribuíram para tal comportamento foram o crescimento da participação das despesas com os benefícios da previdência e com diversos programas da área social implementados a partir da década de 90. Na Previdência, por exemplo, o aumento da participação dos gastos com benefícios deve-se ao crescimento vegetativo da massa beneficiária, bem como aos reajustes do salário mínimo, promovidos durante a década de 90, a Lei Orgânica da Assistência Social (LOAS), o FUNDEF, o mínimo Saúde e o Fundo de Combate à Pobreza (Quadro A1 do Anexo).

Entretanto, no caso das partilhas de receitas tributárias com estados e municípios, a transferência de recursos é automática: se aumentar a receita tributária da União, aumentam os recursos transferidos aos governos estaduais e municipais. Portanto, o desembolso de recursos é automático e não há como o Governo Federal evitar essa despesa ou dedução de receita. Logo, as vinculações de receitas tributárias a transferências constitucionais e legais aos estados e municípios equiparam-se a despesas obrigatórias.

Mas no caso das vinculações de receitas a órgãos, fundos e despesas do próprio Governo Federal, as receitas vinculadas podem ser contingenciadas e, portanto, não desembolsadas (o contingenciamento só não é possível quando a receita está vinculada a uma despesa obrigatória). Podendo haver o contingenciamento, a vinculação de receitas não gera, automaticamente, despesa. Logo, em termos de rigidez da despesa, as receitas vinculadas representam um problema menor que as despesas obrigatórias.

A Tabela 2 mostra algumas fontes de receita que, por lei, têm 100\% de sua arrecadação vinculada a despesas específicas. Fosse plenamente respeitada essa vinculação, as despesas financiadas por tais fontes deveriam ser iguais às receitas. Contudo, o que se vê na Tabela 2 é que, em média, apenas $67 \%$ dos recursos vinculados são, efetivamente, liquidados. Os outros $33 \%$ são contingenciados e não são efetivamente gastos. 
Tabela 2 - Algumas Fontes de Receita 100\% Vinculada; valores arrecadados, liquidados e pagos (2006)

RS Milhões

\begin{tabular}{|c|c|c|c|c|c|}
\hline Fonte de Recursos & $\begin{array}{c}\text { Receita } \\
\text { Arrecadada } \\
\text { Líquida }\end{array}$ & Liquidado & Pago & $\begin{array}{c}\% \\
\text { Liquidado }\end{array}$ & $\%$ Pago \\
\hline & (A) & (B) & (C) & $(D)=(B) /(A)$ & $(E)=(C) /(A)$ \\
\hline 142 - COMPENS.FINANC.P/EXPL.DE PETR.OU GAS.NATURAL & 16.604 & 10.919 & 9.641 & 66 & 58 \\
\hline 111 - CONTRIB.DERIV.PETROLEO,COMB.COM.-CIDE & 6.258 & 5.520 & 2.980 & 88 & 48 \\
\hline 174 - TAXAS PELO EXERCICIO DO PODER DE POLICIA & 3.697 & 1.592 & 1.420 & 43 & 38 \\
\hline 132 - JUROS DE MORA DA RECEITA ADMINIST.PELA SRF/SF & 3.319 & 1.791 & 1.719 & 54 & 52 \\
\hline 134 - COMPENSACOES FINANC.P/UTILIZ.DE REC.HIDRICOS & 1.526 & 1.518 & 1.341 & 99 & 88 \\
\hline 129 - RECURSOS DE CONCESSOES E PERMISSOES & 968 & 242 & 235 & 25 & 24 \\
\hline 131 - SELOS DE CONTROLE, LOJAS FRANCAS - FUNDAF & 242 & 219 & 219 & 91 & 91 \\
\hline 175 - TAXAS POR SERVICOS PUBLICOS & 173 & 126 & 124 & 73 & 72 \\
\hline 139 - ALIENACAO BENS APREENDIDOS-FUNDAF/MPS/FNAS & 45 & 39 & 39 & 86 & 86 \\
\hline 130 - CONTRIBUICAO P/O DES.DA IND.CINEMAT.NACIONAL & 28 & 23 & 20 & 84 & 72 \\
\hline TOTAL & 32.859 & 21.989 & 17.738 & 67 & 54 \\
\hline
\end{tabular}

Fonte: Senado Federal, Sistema Siga Brasil

Note-se, ainda, que o percentual de efetivo pagamento é ainda menor, representando pouco mais da metade dos recursos arrecadados. Ou seja, parte da receita vinculada líquida é jogada para restos a pagar, podendo ser efetivamente paga ou não em exercícios seguintes.

Se não for gasta na finalidade à qual está vinculada, a receita vinculada não pode ser empregada em nenhuma outra despesa (LRF, art. $8^{\circ}$ ). Do ponto de vista de uma gestão fiscal voltada para a geração de superávits primários, destinados ao pagamento de juros da dívida, isso é uma rigidez que atrapalha, pois a parte do superávit gerado a partir do contingenciamento de recursos vinculados não poderá ser usada para pagar os juros da dívida.

Ainda assim, na ótica da autoridade fiscal vale a pena contingenciar os recursos, pois eles ficarão em caixa, consistindo em um ativo do Tesouro e, portanto, reduzindo a dívida líquida do setor público. Certamente seria melhor utilizá-los para pagar juros, evitando a sua capitalização no principal da dívida e, consequentemente, exercendo pressão sobre as taxas de juros, o que um financiamento maior da dívida traz. Mas, do ponto de vista do controle fiscal, tal situação ainda é melhor do que ter que realizar uma despesa obrigatoriamente.

Como se pode ver, uma parcela do superávit primário não pode ser utilizada diretamente para o pagamento de juros e amortizações, devido justamente ao excesso de vinculações de receitas. 
Assim, os recursos restantes do resultado primário ficam esterilizados, servindo apenas para aumentar a disponibilidade de caixa do Tesouro e, indiretamente, reduzir a dívida líquida da União.

Uma solução parcial para esse problema veio com a Desvinculação das Receitas da União (DRU). A desvinculação permite que, pelo menos os $20 \%$ que a DRU desvincula da finalidade original sejam livremente utilizados para pagamento de juros da dívida. Mas isso só se aplica às receitas de impostos, contribuições sociais e contribuições econômicas. Assim, valores relativos a receitas de taxas ou de compensações financeiras não estariam sujeitos ao mecanismo da DRU.

Além disto, percebe-se que diversas entidades constantes do orçamento procuram assegurar um nível de proteção contra a repressão fiscal e a redução real de seus recursos orçamentários por uma eventual inflação, utilizando-se da vinculação de receitas a determinadas despesas (AZEVEDO, 2006). Ao agirem dessa forma, esperam estar garantindo estes seus recursos contra mudanças inesperadas que possam vir a ocorrer na política econômica do governo, como por exemplo, uma crise financeira internacional com reflexo nas finanças públicas do Governo Federal.

De fato, pode-se observar que foram criadas e depois anualmente incrementadas, destinações específicas para as receitas do Governo Federal, o que originou uma elevação significativa na parcela correspondente às receitas vinculadas no orçamento da União. Aliado ao aumento da arrecadação vinculada, houve um crescimento significativo das despesas obrigatórias com a Previdência Social, Pessoal, Assistência Social e Saúde. Este aumento está diretamente associado ao crescimento da participação das contribuições sociais no total de recursos arrecadados, tanto devido à criação de novas contribuições, tal como a Contribuição Provisória sobre Movimentação Financeira (CPMF), quanto ao aumento das alíquotas de contribuições já existentes, tais como Contribuição Social sobre o Lucro Líquido (CSLL) e Contribuição para o Financiamento da Seguridade Social (COFINS) (BRASIL, 2003).

Como se pode verificar, o crescente engessamento do orçamento brasileiro transformou-o num instrumento muito rígido, com excessivo grau de vinculação de receitas e elevado nível de despesas constitucional e legalmente obrigatórias (MORA, 2005). Lembre-se, ainda, que a LRF determina que as receitas vinculadas sejam utilizadas exclusivamente para atender o objeto de sua vinculação, ainda que em exercício diverso daquele em que ocorrer o ingresso (STN, 2009, b).

Não obstante, mesmo com a disciplina fiscal alcançada com a LRF, "há o entendimento de que reformas adicionais são necessárias para aumentar a flexibilidade dos gastos e reduzir o déficit da Previdência Social" (GOLDFAJN, 2002, p. 10). 


\subsection{Vantagens e desvantagens da vinculação de receitas}

A teoria tradicional de finanças públicas opõe-se a qualquer vinculação, por esta impor restrições à maximização do benefício social em vista de algumas possíveis distorções. Primeiramente, porque mesmo nos modelos mais simples, a alocação de recursos públicos deve ser feita de tal forma que cada unidade monetária adicional deva prioritariamente ser gasta em ações que permitissem o maior benefício social. Independentemente do modelo de vinculação, mesmo quando direcionada a gastos prioritários e inicialmente correlacionados com certas despesas, a vinculação, publicada necessariamente em algum normativo legal, possibilita que o processo orçamentário fique vulnerável a criação de riscos de ineficiências, pois frequentemente as prioridades alterarem-se ao longo do tempo, muitas vezes sem reflexos nas vinculações para as quais foram originalmente definidas.

Na prática a vinculação de receitas tende a criar uma serie de ineficiências na formulação e execução do orçamento. Em primeiro lugar, mesmo que a real demanda por recursos diminua com o tempo, a perspectiva de um fluxo de receitas garantido tende a levar à procura de novas despesas que o justifiquem. Cria-se, assim, um efeito simultaneidade, onde o aumento de receitas vinculadas parece justificado pelo aumento das despesas. Na verdade, muitas vezes, o automatismo do gasto é causado pela vinculação e se reflete principalmente em um esforço para que o orçamento seja plenamente executado independente da pertinência do gasto, como forma de legitimar a vinculação conferida pela legislação.

A vinculação de receitas muitas vezes também tem efeitos assimétricos, ou seja, mesmo executando despesas de baixa prioridade, os recursos destinados para os setores previamente definidos são plenamente usados e pior ainda se houver frustração da receita vinculada, as despesas correspondentes não são automaticamente reduzidas. Elas irão, portanto, pressionar a disputa pelos recursos de livre programação, que por força do excesso de vinculações já constituem pequena fração da receita primária.

Outras vezes, ela incentiva a chamada inversão de prioridades. Isto ocorre quando os órgãos que contam com receitas vinculadas tendem a executar, com esses recursos, os gastos de menor importância na escala de prioridade geral do governo, de forma a pressionar o Tesouro Nacional, posteriormente, para lhe alocar adicionalmente recursos necessários para o atendimento de despesas incompressíveis. 
Apesar das desvantagens demonstradas, existem casos em que a vinculação de receitas pode representar uma forma eficiente de alocação de recursos. São casos específicos e muito bem delimitados. Por exemplo, com base na teoria da escolha pública, podem existir casos em que os bens e serviços providos pelo setor público apresentam características de bens privados e não envolvam aspectos meritórios. Estes casos justificariam o estabelecimento de cobrança de receitas incidente somente sobre os consumidores desses bens, que deveriam ser usadas para a recuperação dos custos envolvidos no seu provimento. Esse procedimento amplia a eficiência do processo, igualando a provisão pública de bens/serviços com características privadas ao desejo de consumo, e impondo o ônus financeiro sobre o beneficiário do consumo, sendo denominado princípio do benefício. Em geral, essa forma de vinculação, para funcionar adequadamente, requer ser a única fonte de financiamento do bem/serviço, e ser integralmente utilizada nas despesas previstas.

O desejo de proteger gastos prioritários também pode ser apontado como justificativa para o estabelecimento de receitas vinculadas. A vinculação evitaria que gastos prioritários fossem vitima de grandes flutuações, que poderiam decorrer da discricionariedade do processo orçamentário. No caso de despesas obrigatórias, a vinculação procuraria garantir que estas não deixassem de ser executadas por ausência de fundos adequados. A vinculação nesses casos pressupõe uma divergência entre as prioridades do Legislador ou do Governo e as da população, possivelmente pela presença de desafios de curto prazo que incentivem o dispêndio em atividades que no longo prazo não maximizem o bem estar social.

\section{Evoluções e soluções do problema ao longo do tempo}

\subsection{O contigenciamento e a política fiscal superavitária}

O contingenciamento é um procedimento adotado pelo governo, com base no seu poder regulamentar para assegurar o equilíbrio orçamentário entre receitas e despesas. Por meio desse procedimento, o Poder Executivo limita a realização da despesa orçamentária a montantes inferiores aos autorizados na LOA e nos créditos adicionais, com vistas a evitar que os gastos excedam aos valores efetivamente arrecadados em cada exercício financeiro.

Segundo Mendes (2008), nos últimos anos, os mais importantes instrumentos utilizados pelos gestores de finanças públicas são: o contingenciamento de despesas, principalmente das 
despesas de investimento e a elevação da carga tributária, especialmente através da expansão das contribuições sociais.

Como afirma Azevedo, o contingenciamento é:

(...) um procedimento adotado pelo governo, com base no seu poder regulamentar, para assegurar o equilíbrio orçamentário entre receitas e despesas. Por meio desse procedimento, o Poder Executivo limita a realização da despesa orçamentária a montantes inferiores aos autorizados na lei orçamentária e nos créditos adicionais, com vistas a evitar que os gastos excedam aos valores efetivamente arrecadados em cada exercício financeiro (AZEVEDO, 2006, p.82).

De tal forma, que para conter a forte rigidez orçamentária e o acelerado ritmo crescimento da despesa obrigatória e da vinculação de receita, o governo foi obrigado a elevar a carga tributária ano após ano, além de contingenciar despesas e reprimir investimentos (MENDES, 2008). Todavia é interessante lembrar que pela Constituição de 1988, o contingenciamento só poderá incidir sobre a parcela de despesas não obrigatórias, ou seja, as despesas com custeio dos órgãos e as despesas com investimentos do governo (STN, 2009, b).

Nos últimos anos, o contingenciamento da despesa tem sido o instrumento de ajuste adotado pelo governo. Os cortes que deveriam ser temporários, em regra, tornaram-se permanentes, gerando incertezas quanto à realização de determinados gastos contidos no orçamento (despesas discricionárias). O contingenciamento dos gastos não obrigatórios (outras despesas correntes e de capital) suspende e condiciona a execução desses gastos à realização efetiva da receita orçamentária (PIRES JÚNIOR, 2009).

Os decretos de contingenciamento editados pelo Poder Executivo no período de 1990 a 2006 fundamentavam-se no poder regulamentar assegurado pelo artigo 84 da Constituição Federal de 1988. O governo também recorria ao artigo 48 da Lei $4320 / 1964$ e artigo 72 do Decreto-lei $n^{\circ}$. 200/1967. Esses decretos tornavam indisponíveis para saldo as dotações orçamentárias consignadas nas leis orçamentárias para os respectivos exercícios financeiros, bem como os créditos adicionais e as atualizações desses valores.

Os formuladores do Plano Real criticavam o contingenciamento. Para eles, a imposição de limites quantitativos a execução da despesa autorizada na lei orçamentária conduzia a várias distorções, em particular a perda da transparência do processo orçamentário. Além disso, 
afirmavam que o uso do contingenciamento não foi suficiente para resolver os desequilíbrios fiscais.

Após a implementação do Plano Real, entretanto, o governo continuou a fazer uso da política de editar decretos de contingenciamento, cuja fundamentação era a mesma dos decretos anteriores (1990-1994) e mantinham o caráter de instrumento de ajuste das contas públicas.

Com o advento da LRF, o contingenciamento da despesa tornou-se legal. A necessidade de se efetivar o ajuste das contas do setor público, por meio do cumprimento de metas de superávits primários fixados na LDO, passou a ser um fator determinante para a edição dos decretos de contingenciamento. A limitação de empenho e de movimentação financeira (contingenciamento) prevista no artigo $9^{\circ}$. da LRF, assemelha-se ao sequestration, mecanismo existente no Budget Enforcement Act (BEA) dos Estados Unidos (MENDES, 2008).

Em resumo, a LRF estabelece com relação à limitação de empenho e à movimentação financeira (contingenciamento): (i) a LDO fixa as metas de resultado primário e nominal, (ii) a realização da receita deve ser acompanhada de modo contínuo; (iii) caso se verifique que a meta de resultado primário não se cumprirá, todos os poderes e Ministério Público deverão promover limitação de empenho nos valores necessários para assegurar o cumprimento da meta fiscal. A lei determina que haja revisão da limitação de empenho caso ocorra recuperação do nível de arrecadação, devendo as dotações serem recompostas (descontingenciamento da despesa).

A LRF também insere um caracter obrigatório ao contingenciamento ao dispor que se for verificado, ao final de um bimenstre, que a realização de uma receita poderá não comportar a realização de metas de resultado primário ou nominal estabelecidas no Anexo de Metas Fiscais, os Poderes e o Ministério Público deverão promover, por ato próprio e nos montantes necessários, nos trinta dias subsequentes, limitação de empenho e movimentação financeira, segundo critérios fixados pela LDO. (Art. $9^{\circ}$ da Lei de Responsabilidade Fiscal)

Assim, depois de decorrido o bimenstre, o Poder Executivo deve comprovar que a previsão de receitas não permitirá o cumprimento da meta de superávit prevista na LOA, com a devida demonstração de que houve alterações nas premissas e parâmetros que direcionaram a estimativa de receita e/ou a fixação dos gastos públicos.

Pelo disposto na LRF, o primeiro decreto de contingenciamento da despesa deveria ser baixado somente quando transcorrido um bimestre da execução orçamentária. Com autorização dada anualmente pela LOA, o governo edita esse decreto alguns dias após o início da execução orçamentária do exercício. Esse fato indica a importância que o mecanismo de contingenciar 
dotações ganhou como instrumento de ajuste das contas públicas do país. De modo preventivo, antes do final do primeiro bimestre, o governo editou os primeiros decretos de contingenciamento nos anos de 2001-2006 (AZEVEDO, 2006).

Entre os anos de 1998-2004 pelo lado da arrecadação a realização da receita superou as estimativas da LOA. Contudo, do lado das despesas, em particular, despesas obrigatórias (pessoal e benefícios previdenciários), a execução superou a previsão, o que serviu de justificativa para o governo contingenciar os gastos discricionários. Cabe destacar que os gastos com investimentos sempre ficaram abaixo da média fixada na lei.

Numa visão geral, verifica-se que ao longo dos quatro últimos exercícios financeiros, os contingenciamentos anularam, em parte, os montantes acrescidos na proposta orçamentária pelo Congresso. Em 2004, os cortes superaram o montante acrescido pelo legislativo no Substitutivo. As justificativas para os cortes são as mais variadas. Contudo, o curto lapso temporal que separa a aprovação e a sanção da LOA, praticamente sem vetos à programação orçamentária, e a posterior decretação dos cortes, sugerem um corte indireto no valor proposto nas emendas parlamentares.

\subsection{A expansão das contribuições e seus impactos}

O crescimento da participação das contribuições sociais no total de recursos arrecadados está diretamente associado ao aumento das receitas vinculadas, em decorrência tanto da criação de novas contribuições, como foi o caso da Contribuição Provisória sobre Movimentação Financeira (CPMF), quanto do aumento de alíquotas - como foram os casos da Contribuição Social sobre o Lucro Líquido (CSLL) e da Contribuição para o Financiamento da Seguridade Social (COFINS). Aumentos estes que em alguns casos foram provisórios, enquanto em outros permanentes.

Vale a pena comentar que, se por um lado houve o esforço do Governo para desvinculação destas receitas, por outro lado este esforço foi acompanhado pelo aumento da vinculação de recursos para a Seguridade Social e por despesas obrigatórias, ou conforme argumenta Mora:

(...) o aumento da carga tributária - e, consequientemente, o dos recursos disponíveis - não representou melhoria na provisão dos serviços públicos. No debate sobre desvinculação, discute-se também o grau de eficiência do governo e espera-se que a redução dos recursos disponíveis seja acompanhada de um choque de gestão para aumentar a eficácia do gasto federal (MORA, 2005, p.105). 
Como se pode verificar a simples proposta de aumentar a carga tributária como instrumento para elevar o superávit primário “(...) só é viável com a desvinculação de gastos, pois aumento da carga tributária, é contraproducente pelo elevado comprometimento de receita com rubricas específicas" (MORA, 2005, p. 105). O impacto das vinculações no âmbito do Governo Federal é tal que um eventual aumento da carga tributaria resultaria em uma geração muito reduzida de receitas de aplicação livre.

Como podemos verificar no gráfico 6 , as receitas de contribuições sociais administradas pela SRF aumentaram sua participação de 4,6\%, em 1995, para 7,7\%, em 2002, o que equivale a uma elevação de sua carga fiscal em 69\% em termos de participação no PIB, chegando a corresponder por volta de $46 \%$ do total das receitas administradas pela SRF em 2002.

\section{Gráfico 6 - Evolução dos Principais Impostos versus Contribuições Sociais}

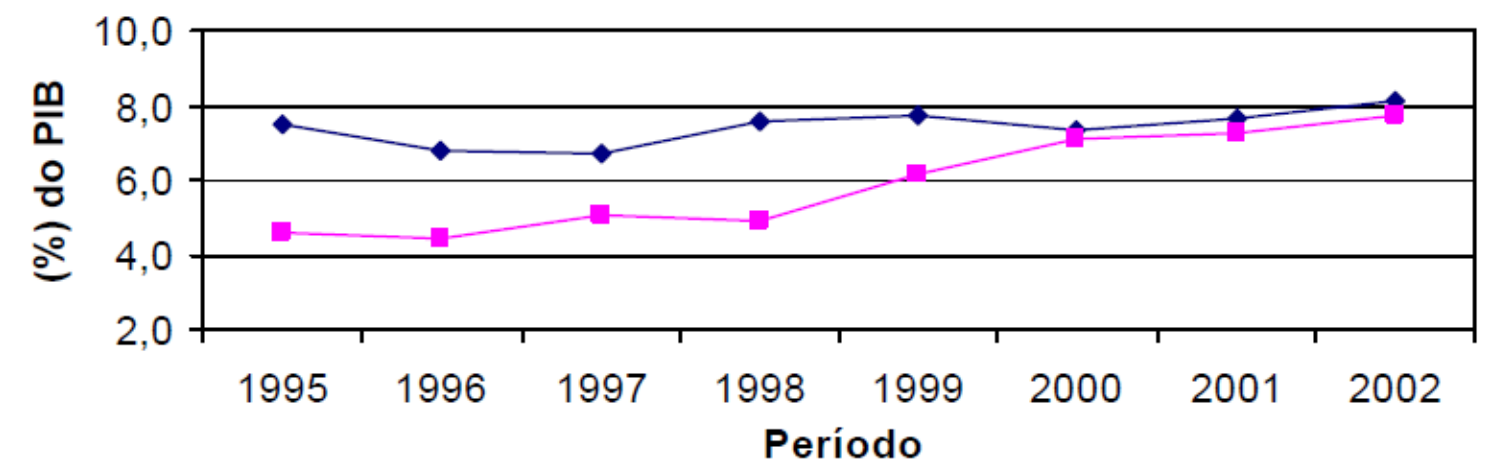

$\longrightarrow$ Receita de Impostos

$\rightarrow$ - Receita de Contribuições

Fonte: MF/SRF

Observa-se que esse aumento foi caracterizado pela expansão das Contribuições Sociais, o que constitui um artifício para evitar a partilha dos recursos com estados e municípios, ou seja, o governo optou por elevar suas receitas via Contribuições Sociais como uma estratégia para não repartir recursos com as transferências automáticas a estados e municípios. Entretanto, esta estratégia não foi muito eficiente, pois segundo Mendes (2008, p. 4) "a conseqüência desse procedimento foi o inchaço da receita do Orçamento da Seguridade Social, exigindo que se criasse um mecanismo para repassar parte dos recursos para o Orçamento Fiscal”. Como veremos na seção 3.3., esse mecanismo foi a DRU. 
Segundo STN (2009, a), o cálculo do resultado primário, é a diferença entre as receitas totais, excluindo os ganhos de aplicações financeiras, e gastos totais, também excluindo os juros nominais devidos. O principal objetivo desse cálculo é avaliar a sustentabilidade da política fiscal, tendo em vista o patamar atual da dívida consolidada e a capacidade de pagamento da mesma pelo setor público no longo prazo. Quando esta diferença é positiva obtem-se superávit, quando negativa obtem-se déficit primário.

Segundo Albuquerque, Medeiros e Feijó (2006), se os superávits primários fossem direcionados ao serviço da dívida, contribuiriam para reduzir o estoque total da dívida líquida. Por outro lado, ocorrências de déficits primários indicam que a parcela do crescimento da dívida decorrente de financiamentos de gastos não-financeiros, excede as receitas não-financeiras e demonstram falta de controle dos gastos federais. Esses gastos são diretamente associados às despesas obrigatórias e às receitas vinculadas, de tal forma que comprometem cada vez mais os recursos orçamentários da união, dificultando a manutenção da meta fiscal e o controle da Divida Pública. O governo tanto poderia trabalhar pelo aumento da receita como pelo controle do crescimento desordenado dos gastos correntes federais.

O argumento de tentar aumentar a receita através da elevação carga tributária, que já é exageradamente alta para um país de renda per capita média como o Brasil, é totalmente contraproducente devido o alto comprometimento da receita com rubricas específicas. Todavia a necessidade de garantir a estabilização da dívida em face das políticas de gasto e seus reflexos monetários redundou na elevação da carga tributária até 2008, como se pode observar no Gráfico 7. 


\section{Gráfico 7 - Elevação da Carga Tributária}

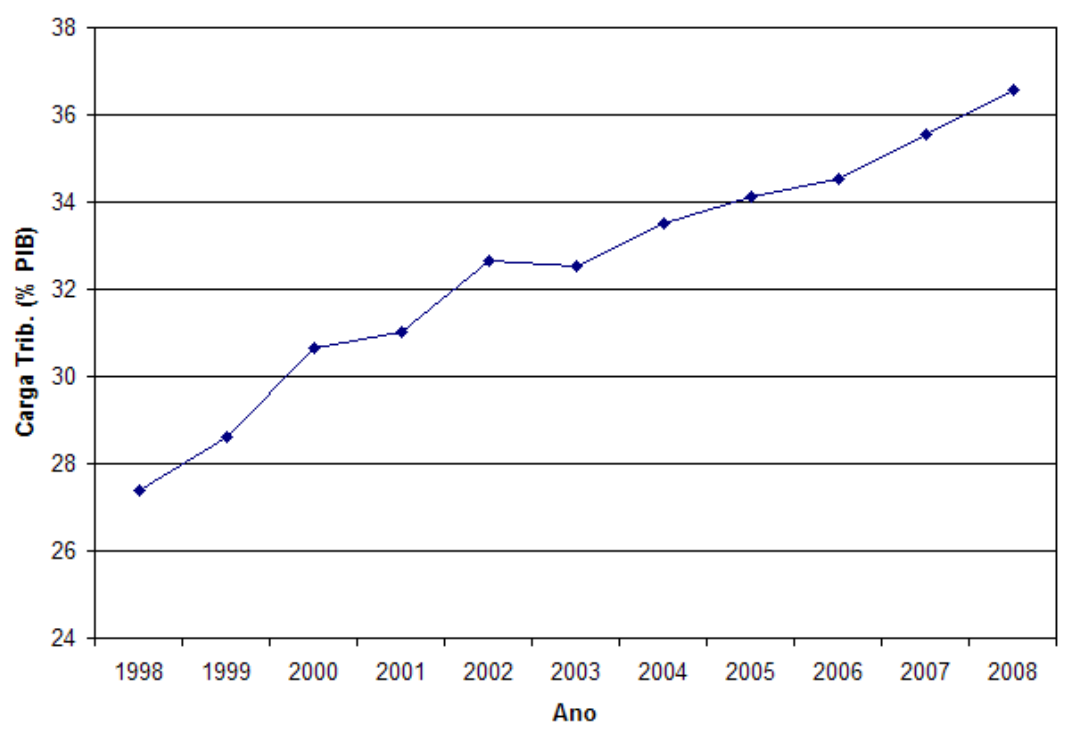

Fonte: MF/SRF

Como então explicar que, mesmo com as despesas do Orçamento da Seguridade crescendo em ritmo tão acelerado, tenha sido possível transferir recursos daquele Orçamento para o Orçamento Fiscal?

A resposta é simples. Como ainda veremos na seção 3.3., o governo optou por elevar suas receitas via contribuições sociais como uma estratégia de não repartir (DRU) recursos com estados e municípios. Mas o aumento de receita de contribuições sociais, desde seu início, visava à geração de receitas para pagar despesas em geral, tanto do Orçamento Fiscal quanto do Orçamento da Seguridade. Os recursos só foram contabilizados no Orçamento da Seguridade por uma questão formal, por serem chamados de "contribuições sociais". A Contribuição Social sobre o Lucro Líquido (CSLL) é um bom exemplo. Na prática ela não passa de um Imposto de Renda (IR) adicional cobrado das empresas. Inclusive, nas propostas de reforma tributária apresentadas pelo Poder Executivo, a CSLL seria efetivamente incorporada ao IR. Mas, no atual ordenamento constitucional, se chamarmos a CSLL de "Imposto" o Governo Federal terá que partilhar 20\% da arrecadação com estados e municípios (PIRES JÚNIOR, 2009).

Não é cabível afirmar que toda a receita de contribuições deve pertencer ao Orçamento da Seguridade, simplesmente porque o País não pode fazer apenas gasto em seguridade, precisando saldar compromissos em diversas outras áreas. É evidente que grupos políticos associados à área da seguridade utilizam o argumento de que as receitas de contribuição devem ficar com a seguridade e que, por isso, poderiam aumentar ainda mais as despesas com saúde, aposentadorias e benefícios 
sociais. Mas, se fosse assim, de onde sairia o dinheiro para pagar todas as outras despesas do governo?

No cálculo do resultado primário, estes recursos resultantes do aumento da carga tributária ficam estocados e servem apenas para aumentar a disponibilidade de Caixa do Governo Federal e indiretamente, reduzir a Dívida Líquida da União. Ao permanecerem no Caixa do Tesouro, eles aumentam o superávit primário e ajudam ao Governo a manter estável e sob controle a relação Dívida/PIB, relação essa continuamente observada pelo mercado (PIRES, 2006).

É conveniente observar que também existe o perigo de gerarem-se superávits primários sem se exercer um efetivo controle sobre as despesas correntes, isto é, se o superávit basear-se mais no crescimento da receita do que em cortes no orçamento (SAMUELS, 2002). De qualquer forma, percebe-se que a preocupação da política fiscal em gerar crescentes superávits vem agregando ganhos para a credibilidade do país (investiment grade) e espera-se que no futuro a Dívida Pública seja reduzida, o que também criaria espaço para redução do esforço fiscal do governo. Em outras palavras, o regime fiscal atual tem criado expectativas de consistência na gestão da Dívida Pública, o que implica ganhos de credibilidade (PIRES, 2006).

Essa credibilidade é reforçada pelo esperado declínio da relação dívida/PIB ao longo dos próximos anos, declínio esse cuja condição chave necessária é o contínuo crescimento do superávit primário em relação ao PIB (GOLDFAJN, 2002). Ainda segundo Goldfajn (2002);

(...) se um cenário, pouco provável, mas negativo se materializar, correções posteriores na relação entre receitas e despesas são factíveis. O conforto surge do progresso institucional recente no regime fiscal no Brasil, em particular a Lei de Responsabilidade Fiscal e os acordos com os estados e municípios (GOLDFAJN, 2002, p. 26).

Finalizando, com a excessiva preocupação em aumentar a arrecadação, o governo não deveria se esquecer que, no âmbito da macroeconomia, uma das principais ações para se poder evitar a vulnerabilidade das políticas fiscais é priorizar a redução da divida pública para patamares que permitam ao setor publico desenvolver uma flexibilidade na capacidade de poupar. Deve-se lembrar novamente da necessidade de reformas estruturais micro-econômicas e medidas que diminuam o risco da economia e aumentem a sua eficiência, as quais tendem a facilitar a redução dos prêmios de risco implícitos na taxa de juros requerida pelos tomadores da divida pública, além de estimular o crescimento econômico, aumentando o denominador da relação divida/PIB. Neste 
sentido, atenuar o viés fiscal expansionista introduzido por vinculações de receitas contribui para aumentar a percepção da solvência do setor publico, com desdobramentos positivos no custo da divida pública. Nestas circunstancias, a autoridade fiscal e o Congresso aumentam sua capacidade para lidar adequadamente com a questão do ciclo econômico (GOLDFAJN, 2002).

\subsection{Um mecanismo para lidar com o excesso de vinculação de receitas - criação da DRU}

A Desvinculação de Recursos da União (DRU) é um mecanismo, que segundo Mendes:

(...) embora seja um precário instrumento de gestão orçamentária, é bastante importante, por evitar que a excessiva vinculação de receitas seja um mal maior. A manutenção da DRU ao longo dos anos permitiria que se concentrasse o capital político do governo na flexibilização da despesa obrigatória e semiobrigatória, que constitui o principal problema das finanças federais (MENDES, 2008, p. 4).

Realmente a "DRU é um mecanismo de carácter temporário, tendo em vista a expectativa de reformas estruturais para assegurar a flexibilização no nível das vinculações existentes" (AZEVEDO, p. 128). Para a autoridade fiscal fazer gestão da Dívida Pública, observa-se que a DRU demonstrou ser um instrumento importante, mas não suficiente para resolver a questão de flexibilidade da política fiscal. Tanto que Mendes considera a DRU uma solução parcial para o problema, que afirma:

A desvinculação permite que, pelo menos os $20 \%$ que a DRU desvincula da finalidade original sejam livremente utilizados para pagamento de juros da dívida. Mas isso só se aplica a receita de impostos, contribuições sociais e contribuições econômicas. Assim, valores relativos a receitas de taxas ou de compensações financeiras não estariam sujeitos ao mecanismo da DRU (MENDES,2008, p. 30).

A necessidade de ajustamento fiscal e as dificuldades para obter resultados primários decorrentes do elevado percentual de vinculação induziram o governo a apoiar, em 1994, a aprovação do Fundo Social de Emergência (FSE) ${ }^{1}$ que previa a desvinculação de $20 \%$ das receitas federais. Posteriormente, mais precisamente em 1996, o FSE foi substituído pelo Fundo de

\footnotetext{
1 Instaurado pela emenda constitucional de Revisão 1, de 01/03/1994.
} 
Estabilização Fiscal (FEF) ${ }^{2}$ e por fim, em 2000, alteraram a nomenclatura para Desvinculação de Recursos da União (DRU) ${ }^{3}$. Esse novo mecanismo de desvinculação de receita (DRU) vigoraria, inicialmente, até 2003, mas foi prorrogado até 2007, e recentemente prorrogado de novo até 2011. Todos eles seguiram a mesma lógica e buscaram assegurar maior liberdade de gestão dos recursos federais. Para exemplificar, a previsão de receitas e a perspectiva de retenção via DRU estão explicitadas no Quadro A4 do anexo, para o ano de 2006.

Apesar de a DRU contribuir para a ampliação dos recursos livres do orçamento Fiscal da União, a obrigatoriedade de pagamento de algumas despesas acaba revertendo essa situação. Podese dizer que grande parte desses recursos desvinculados pela DRU acaba sendo utilizado para cobrir o déficit do orçamento da Seguridade Social (despesa obrigatória) e não para pagamento de juros e amortização da Dívida, como pensa grande parte da população. Por exemplo, a Lei no 10.407, de 10 de janeiro de 2002 - Lei Orçamentária Anual - LOA 2002, aloca R\$ 17,2 bilhões de receitas do orçamento Fiscal para o financiamento das despesas do orçamento deficitário da Seguridade Social. Na LOA, o montante de receitas de contribuições sociais desvinculadas por meio da DRU é de R\$ 20,5 bilhões. Assim, apenas R \$ 3,3 bilhões são efetivamente liberados para serem utilizados livremente no orçamento Fiscal, conforme tabela 3 a seguir.

Tabela 3 - Recursos da DRU Liberados para o Orçamento Fiscal

\begin{tabular}{|c|c|c|c|}
\hline Descrição & Receita & Despesa & Diferença \\
\hline Orçamento Fiscal (*) & $280.103,7$ & $262.889,2$ & $17.214,5$ \\
\hline Orçamento Seguridade Social & $149.838,2$ & $167.052,8$ & $(17.214,5)$ \\
\hline Refinanciamento da Dívida Pública & $220.467,7$ & $220.467,7$ & - \\
\hline Total & $650.409,6$ & $650.409,6$ & 0,0 \\
\hline
\end{tabular}

Fonte Brasil, 2003

Observa-se no Quadro A2 e A3 do anexo, que a despeito de certa flexibilidade conferida pela DRU ao Governo Central, os aumentos absolutos de receitas são predominantemente absorvidos por vinculações estabelecidas em lei. Entre 2004-2005, as estimativas iniciais sugeriam que a carga tributária deveria se elevar em mais de $1 \%$ do PIB, superando os $37 \%$ do PIB. Em

\footnotetext{
2 Instaurado pela emenda constitucional 10, de 04/03/1996.

3 Instaurado pela emenda constitucional 27, de 21/03/2000.
} 
grande medida, isso se deveria aos aumentos de arrecadação no âmbito do Orçamento Fiscal da União. A elevação das receitas, contudo, pouco representou em termos de maior flexibilidade para o governo federal, conforme demonstrado pelo Quadro A2 do anexo. A receita administrada pela Receita Federal cresceu R\$16,5 bilhões, enquanto a receita não vinculada (já incluída da DRU) aumentou somente em $\mathrm{R} \$ 6,5$ bilhões.

A análise dos gastos federais, tais como apresentados no Resultado Primário do Governo Central (ver Quadro A5 do Anexo), publicado pela Secretaria do Tesouro Nacional (STN), demonstrava que os recursos desvinculados foram preponderantemente utilizados para a obtenção do superávit primário e para os gastos com as despesas consideradas ressalvadas, gastos não necessariamente vinculados a um determinado tributo, mas sujeitos às regras específicas (destacadamente, os gastos realizados pelos ministérios da Saúde e do Desenvolvimento Social e de Combate à Pobreza). Porém, convém lembrar que emendas constitucionais estipularam tetos para os gastos com a Saúde e para os gastos com o Desenvolvimento Social e Combate à Pobreza. É verdade que ambos são parcialmente financiados pela CPMF, mas os tetos estabelecidos requerem a suplementação por meio de recursos do orçamento fiscal.

O Ministério do Planejamento, Orçamento e Gestão (MPOG) realizou um estudo, no qual estimava que o ganho efetivo para o Governo Federal com a DRU, foi em torno de R 7 bilhões por ano, entre 1996 e 1999. Desse montante, o valor de R \$ 2,7 bilhões por ano equivale ao montante não transferido aos estados e municípios. Os efeitos da DRU foram menores, uma vez que este mecanismo não reduz o valor das transferências constitucionais por repartição de receitas a estados e municípios (BRASIL, 2003).

Pelo estudo deste Ministério, pode-se concluir que há um aumento significativo no grau de vinculação das receitas, no governo, quando se faz uma avaliação sem se considerar a existência da DRU. Com a vigência desse dispositivo de libertação de receitas vinculadas, os recursos livres para 2002 foram 14,4\% das receitas totais e de 19,7\% para 2003. Na ausência do mecanismo de desvinculação, os recursos livres caíram para 13,2\% e 12,9\% em 2002 e 2003, respectivamente. Desse modo, pode-se concluir que esse mecanismo realmente aumenta a flexibilidade na execução orçamentária, embora seja um instrumento de execução temporária e dependente de prorrogação. Contudo não se pode esquecer que as vinculações, por outro lado, tem caráter permanente. 


\section{Conclusão}

Observa-se, através deste trabalho, que o sistema orçamentário brasileiro é dominado pelas ações de curto prazo, dando a impressão de não existir um efetivo sistema de planejamento de médio e longo prazo para as políticas do Governo Federal. O sistema de planejamento existente, baseado no Plano Plurianual (PPA) é uma mera formalidade burocrática, conduzida a reboque da execução cotidiana do orçamento.

O foco no curto prazo é decorrente de um sistema fiscal baseado em despesas obrigatórias rígidas e crescentes, que consomem 92\% do orçamento; e em um regime político em que o Poder Executivo tem dificuldade para formar maioria no Congresso. A combinação desses dois ingredientes faz com que o Poder Executivo opere a execução do orçamento com base em dois objetivos: cumprir metas fiscais e atender demandas da base aliada do governo, liberando recursos de interesses de parlamentares e partidos. O sistema tem sido bem sucedido no cumprimento de metas fiscais e parcialmente bem sucedido na composição de maiorias governistas no Congresso. Por outro lado, aparenta quase não se preocupar com a qualidade do gasto e com a relação custobenefício dos programas públicos.

Os principais ingredientes da política de execução do orçamento tem sido o contingenciamento de gastos (em especial de investimentos) e a elevação da carga tributária (via aumento de contribuições sociais). Para que a crescente receita de contribuições sociais seja desvinculada do Orçamento da Seguridade e utilizada para despesas do Orçamento Fiscal (principalmente para pagamento dos juros da dívida pública), utiliza-se, desde 1994, a Desvinculação das Receitas da União (DRU).

No lado das despesas de execução obrigatória, um grande passo já foi dado com a edição da Lei Complementar $\mathrm{N}^{\mathrm{o}} .101$ - Lei de Responsabilidade Fiscal, de 5 de maio de 2000, que define critérios para a criação e / ou expansão dos referidos gastos. Contudo, ainda são necessárias mudanças estruturais, principalmente nas questões relativas à previdência pública e privada e à definição de políticas mais duradouras e consistentes na gestão de recursos humanos do Governo Federal. Estas alterações aumentariam a flexibilidade da política fiscal e, consequentemente, a capacidade do governo atender outras demandas da sociedade.

Para que os gestores públicos consigam gerenciar de maneira mais racional os seus orçamentos, direcionando os gastos públicos para o atendimento de demandas mais prioritárias, fazse necessária, incontestavelmente, a revisão da legislação e uma reforma tributária. Esta reforma 
deve ser acompanhada de mudanças nos critérios de distribuição de transferências Constitucionais e Legais e na questão de vinculações de receitas. Especificamente, na questão das vinculações, estas mudanças poderiam sugerir desde uma simples redução de alíquotas até sua total extinção. Ressaltase que o instrumento de desvinculação temporário de receitas (DRU) vigorará somente até 2010, o que confirma a urgência em se tomar medidas que viabilizem o planejamento orçamentário de maneira mais racional.

Em outras palavras, para se fazer uma alteração constitucional e alterar os percentuais de receitas vinculadas para educação, por exemplo, seria extremamente trabalhoso e dependeria de uma maioria constitucional qualificada. Ao se definir o percentual de vinculação de receita em Saúde e Educação no PPA ou na LDO, o orçamento anual torna-se mais dinâmico e permite-se sua flexibilização na alocação de recursos, segundo suas necessidades mais reais e respectivas variações sazonais.

Como podemos verificar os atuais percentuais de vinculação com educação são baseados em informações e necessidades referentes à Constituição de 1988, necessidades estas que não mais correspondem à realidade atual, ou seja, necessitariam ser atualizadas. Se, por hipótese, em 1988 a Constituição determinasse que $30 \%$ de receita vinculada seriam para gastos em ensino fundamental, hoje, em 2009, já poderíamos verificar uma necessidade diferente, em função da mudança da estrutura demográfica da população.

Estas já referidas alterações seriam extremamente úteis para a melhoria dos resultados primários produzidos, ao reduzir o endividamento bruto da União e ao evitar a esterilização de recursos. Tais recursos criam uma falsa idéia de maior disponibilidade no caixa Tesouro sendo que, na realidade, acabam sendo utilizados para cobrir o déficit do orçamento da Seguridade Social (despesa obrigatória) e não para pagamento de juros e amortização da Dívida, como pensa grande parte da população.

Outra conclusão sugerida por este trabalho é que o Governo Federal deveria atuar somente sobre os fatores que determinam o crescimento acelerado das despesas obrigatórias. A vinculação de receitas até seria um problema menor, pois não necessariamente implica aumento de despesas (exceção feita ao caso das transferências obrigatórias a estados e municípios). O contingenciamento (ainda que de forma precária e gerando ineficiências) evita esse aumento e, paralelamente, a DRU tem permitido o uso de parte do dinheiro contingenciado no pagamento de juros da dívida.

Assim, a tarefa mais importante é estancar o crescimento da despesa obrigatória, para as quais não há o remédio do contingenciamento. No orçamento de 2006, por exemplo, observa-se que 
92\% de toda a despesa primária é obrigatória, o que reflete um alto grau de rigidez do orçamento e mostra a virtual impossibilidade de se fazer grandes ajustes orçamentários de curto-prazo.

Controlar as despesas obrigatórias significa, por exemplo, conceder reajustes reais menos generosos para o salário-mínimo (ou desvincular os benefícios previdenciários do salário-mínimo), adequar os parâmetros de concessão de benefícios previdenciários às mudanças demográficas, flexibilizar a regra de gasto mínimo em saúde e de transferências a estados e municípios, impor limite à autonomia financeira dos poderes autônomos, investirem em uma política de pessoal racional com perspectiva de longo prazo e criar mecanismos legais e de mercado para evitar os sucessivos socorros a dívidas agrícolas.

Feito isso, haverá espaço, por um lado, para a redução da carga fiscal e, por outro, para uma melhor acomodação das emendas parlamentares (devidamente submetidas a um processo de racionalização). Isso deverá reduzir a atual disputa Legislativo-Executivo em torno das estimativas e reestimativas da receita, reduzindo ou eliminando a necessidade do contingenciamento das despesas. A partir daí, poder-se-ia migrar para um orçamento de execução obrigatória (sem contingenciamentos). E, posteriormente, para um efetivo planejamento plurianual do orçamento federal.

Atuar sobre as despesas obrigatórias será uma tarefa hercúlea, que exigirá anos de negociação política e reforma da legislação. Por isso não se deveria tentar, ao mesmo tempo, atuar sobre as vinculações de despesas. A exceção das vinculações a transferências obrigatórias para estados e municípios (que funciona como despesa obrigatória) não se deveria buscar mais desvinculações além daquela já proporcionada pela DRU.

Como já observamos nesse estudo, só será possível construir um sistema orçamentário baseado no planejamento de médio e longo prazo e com foco na qualidade do gasto, quando tiver sido reduzida a rigidez orçamentária através de medidas de flexibilização das despesas obrigatórias. A partir daí será possível ter um sistema orçamentário em que Executivo e Legislativo atuem de forma cooperativa, tanto na estimativa da receita quanto na alocação das despesas. Será possível eliminar o contingenciamento e a DRU e será aberto espaço para a redução da carga tributária, para a expansão do investimento público e para o planejamento da ação governamental de médio e longo prazo. Tudo isto posto, se estaria assegurando importantes ganhos a credibilidade internacional do país (PIRES, 2006).

Finalmente, como última sugestão, poderíamos dizer que com a estabilidade dos preços e a solidez fiscal, surge uma oportunidade para avançar-se no aprimoramento do processo 
orçamentário. A exemplo do que vem acontecendo em outros países, deve-se estabelecer um novo tipo de equilíbrio entre a flexibilidade para se atingir metas fiscais pré-estabelecidas, o desenvolvimento, a transparência, o fortalecimento do Congresso, a governabilidade e a capacidade de execução do gestor público. Este talvez, seja o momento para iniciar-se a discussão sobre um modelo de orçamento que utilize percentuais variáveis para as vinculações de receita ainda na elaboração do PPA ou da LDO e que continuariam variando nos próximos exercícios como forma alternativa ao percentual fixo, imposto na constituição de 1988 (ex: percentual do FPM vinculado para educação). Sugestão esta, semelhante à técnica do orçamento deslizante (rolling multi-annual budget), ou seja, utilizaria-se o orçamento plurianual (PPA) detalhado, com reavaliações anuais das receitas vinculadas (GIACOMONI, 2005), de forma tal que seria uma interessante alternativa para flexibilizar a rigidez presente no orçamento atual. 


\section{Anexos}

\section{Quadro A1}

PRINCIPAIS MECANISMOS DE VINCULAÇÃO E DEFINIÇÃO DE PATAMARES DE GASTO

\begin{tabular}{|c|c|c|}
\hline Item & Disposição & Redação constitucional \\
\hline $\begin{array}{l}\text { Fundo de } \\
\text { Participação de } \\
\text { Estados e } \\
\text { Municípios }\end{array}$ & $\begin{array}{l}\text { Constituição } \\
\text { Federal, artigo } 159\end{array}$ & $\begin{array}{l}\text { I - do produto da arrecadação dos impostos sobre renda e proventos de qualquer natureza } \\
\text { e sobre produtos industrializados, quarenta e sete por cento na seguinte forma: } \\
\text { a) vinte e um inteiros e cinco décimos por cento ao Fundo de Participação dos Estados e do } \\
\text { Distrito Federal; } \\
\text { b) vinte e dois inteiros e cinco décimos por cento ao Fundo de Participação dos Municípios; } \\
\text { c) três por cento, para aplicação em programas de financiamento ao setor produtivo das } \\
\text { Regiões Norte, Nordeste e Centro-Oeste, através de suas instituições financeiras de caráter } \\
\text { regional, de acordo com os planos regionais de desenvolvimento, ficando assegurada ao } \\
\text { semi-árido do Nordeste a metade dos recursos destinados à região, na forma que a lei } \\
\text { estabelecer; } \\
\text { II - do produto da arrecadação do imposto sobre produtos industrializados, dez por cento } \\
\text { aos Estados e ao Distrito Federal, proporcionalmente ao valor das respectivas exportações } \\
\text { de produtos industrializados. }\end{array}$ \\
\hline Cide combustíveis & $\begin{array}{l}\text { Constituição } \\
\text { Federal, artigo } 159\end{array}$ & $\begin{array}{l}\text { III - do produto da arrecadação da contribuição de intervenção no domínio econômico } \\
\text { prevista no art. } 177, \S 4^{\circ}, 29 \% \text { (vinte e nove por cento) para os Estados e o Distrito } \\
\text { Federal, distribuídos na forma da lei, observada a destinação a que se refere o inciso II, c, } \\
\text { do referido parágrafo. } \\
\S 1^{0} \text { Para efeito de cálculo da entrega a ser efetuada de acordo com o previsto no inciso I, } \\
\text { excluir-se-á a parcela da arrecadação do imposto de renda e proventos de qualquer } \\
\text { natureza pertencente aos Estados, ao Distrito Federal e aos Municípios, nos termos do } \\
\text { disposto nos arts. 157, I, e 158, I. } \\
\S 4^{\circ} \text { Do montante de recursos de que trata o inciso III que cabe a cada Estado, vinte e } \\
\text { cinco por cento serão destinados aos seus Municípios, na forma da lei a que se refere } 0 \\
\text { mencionado inciso. }\end{array}$ \\
\hline ITR & $\begin{array}{l}\text { Constituição } \\
\text { Federal, artigo } 158\end{array}$ & $\begin{array}{l}\text { II - cinqüenta por cento do produto da arrecadação do imposto da União sobre a } \\
\text { propriedade territorial rural, relativamente aos imóveis neles situados, cabendo a } \\
\text { totalidade na hipótese da opção a que se refere } 0 \text { art. } 153, \S 4^{\circ} \text {, III; }\end{array}$ \\
\hline $\begin{array}{l}\text { Novos impostos } \\
\text { criados pela União }\end{array}$ & $\begin{array}{l}\text { Constituição } \\
\text { Federal, artigo } 157\end{array}$ & $\begin{array}{l}\text { II - vinte por cento do produto da arrecadação do imposto que a União instituir no } \\
\text { exercício da competência que lhe é atribuída pelo art. 154, I. }\end{array}$ \\
\hline IOF ouro & $\begin{array}{l}\text { Constituição } \\
\text { Federal, artigo } 153\end{array}$ & $\begin{array}{l}\S 5^{\circ} 0 \text { ouro, quando definido em lei como ativo financeiro ou instrumento cambial, sujeita- } \\
\text { se exclusivamente à incidência do imposto de que trata o inciso V do caput deste artigo, } \\
\text { devido na operação de origem; a alíquota mínima será de um por cento, assegurada a } \\
\text { transferência do montante da arrecadação nos seguintes termos: } \\
\text { I - trinta por cento para o Estado, o Distrito Federal ou o Território, conforme a origem; } \\
\text { II - setenta por cento para o Município de origem. }\end{array}$ \\
\hline
\end{tabular}

Fonte Boletim Conjuntura, dez 2005 
Quadro A1 (continuação)

(continuaçăo)

\begin{tabular}{|c|c|c|}
\hline Item & Disposição & Redação constitucional \\
\hline $\begin{array}{l}\text { Fundo de } \\
\text { Combate e } \\
\text { Erradicação à } \\
\text { Pobreza }\end{array}$ & $\begin{array}{l}\text { Constituição } \\
\text { Federal; ADCT; } \\
\text { art. } 81\end{array}$ & $\begin{array}{l}\text { Art. } 79 \text {. É instituido, para vigorar até o ano de } 2010 \text {. } \\
\text { Art. } 81 \text {. É instituido Fundo constituido pelos recursos recebidos pela União em decorrência } \\
\text { da desestatização de sociedades de economia mista ou empresas públicas por ela } \\
\text { controladas, direta ou indiretamente, quando a operaçäo envolver a alienação do } \\
\text { respectivo controle acionário a pessoa ou entidade não integrante da Administraçăo } \\
\text { Pública, ou de participação societária remanescente após a alienação, cujos rendimentos, } \\
\text { gerados a partir de } 18 \text { de junho de } 2002 \text {, reverterão ao Fundo de Combate e Erradicação } \\
\text { de Pobreza. } \\
\S 1^{\circ} \text { Caso o montante anual previsto nos rendimentos transferidos ao Fundo de Combate e } \\
\text { Erradicação da Pobreza, na forma deste artigo, não alcance o valor de quatro bilhões de } \\
\text { reais, far-se-á complementação na forma do art. } 80 \text {, inciso IV, do Ato das Disposiçöes } \\
\text { Constitucionais Transitórias. } \\
\S 2^{\circ} \text { Sem prejuizo do disposto no } \S 1^{\circ}, 0 \text { Poder Executivo poderá destinar ao Fundo a que } \\
\text { se refere êste artigo outras receitas decorrentes da alienaçăo de bens da União. }\end{array}$ \\
\hline CPMF & $\begin{array}{l}\text { Constituiçăo Federal; } \\
\mathrm{ADCT} \text {; art. } 84\end{array}$ & $\begin{array}{l}\S 2^{\circ} \text { Do produto da arrecadação da contribuição social de que trata este artigo será } \\
\text { destinada a parcela correspondente à aliquota de: } \\
\text { I- vinte centésimos por cento ao Fundo Nacional de Saúde, para financiamento das ações } \\
\text { e serviços de saúde; } \\
\text { II - dez centésimos por cento ao custeio da previdência social; } \\
\text { III - oito centésimos por cento ao Fundo de Combate e Erradicação da Pobreza, de que } \\
\text { tratam os arts. } 80 \text { e } 81 \text { deste Ato das Disposições Constitucionais Transitórias. }\end{array}$ \\
\hline Educação & $\begin{array}{l}\text { Constituição Federal; } \\
\text { art. } 212\end{array}$ & $\begin{array}{l}\text { Art. 212. A União aplicará, anualmente, nunca menos de dezoito, e os Estados, o Distrito } \\
\text { Federal e os Municípios vinte e cinco por cento, no mínimo, da receita resultante de } \\
\text { impostos, compreendida a proveniente de transferências, na manutenção e } \\
\text { desenvolvimento do ensino. }\end{array}$ \\
\hline Salário educação & $\begin{array}{l}\text { Constituição Federal; } \\
\text { art. } 212\end{array}$ & $\begin{array}{l}\S 5^{\circ} 0 \text { ensino fundamental público terá como fonte adicional de financiamento a } \\
\text { contribuição social do salário-educação, recolhida pelas empresas, na forma da lei. }\end{array}$ \\
\hline Saúde & $\begin{array}{l}\text { Constituição, ADCT, } \\
\text { art. } 77\end{array}$ & $\begin{array}{l}\text { "a) no ano 2000, o montante empenhado em ações e serviços públicos de saúde no } \\
\text { exercício financeiro de } 1999 \text { acrescido de, no mínimo, cinco por cento;" "b) do ano } 2001 \\
\text { ao ano 2004, o valor apurado no ano anterior, corrigido pela variação nominal do Produto } \\
\text { Interno Bruto - PIB;" (AC) "II - no caso dos Estados e do Distrito Federal, doze por cento } \\
\text { do produto da arrecadação dos impostos a que se refere o art. } 155 \text { e dos recursos de que } \\
\text { tratam os arts. } 157 \text { e 159, inciso I, alínea a, e inciso II, deduzidas as parcelas que forem } \\
\text { transferidas aos respectivos Municípios; } \S 4^{\circ} \text { Na ausência da lei complementar a que se } \\
\text { refere } 0 \text { art. 198, } \S 3^{\circ} \text {, a partir do exercicio financeiro de } 2005 \text {, aplicar-se-á à União, aos } \\
\text { Estados, ao Distrito Federal e aos Municípios o disposto neste artigo. }\end{array}$ \\
\hline
\end{tabular}

Fonte Boletim Conjuntura, dez 2005 


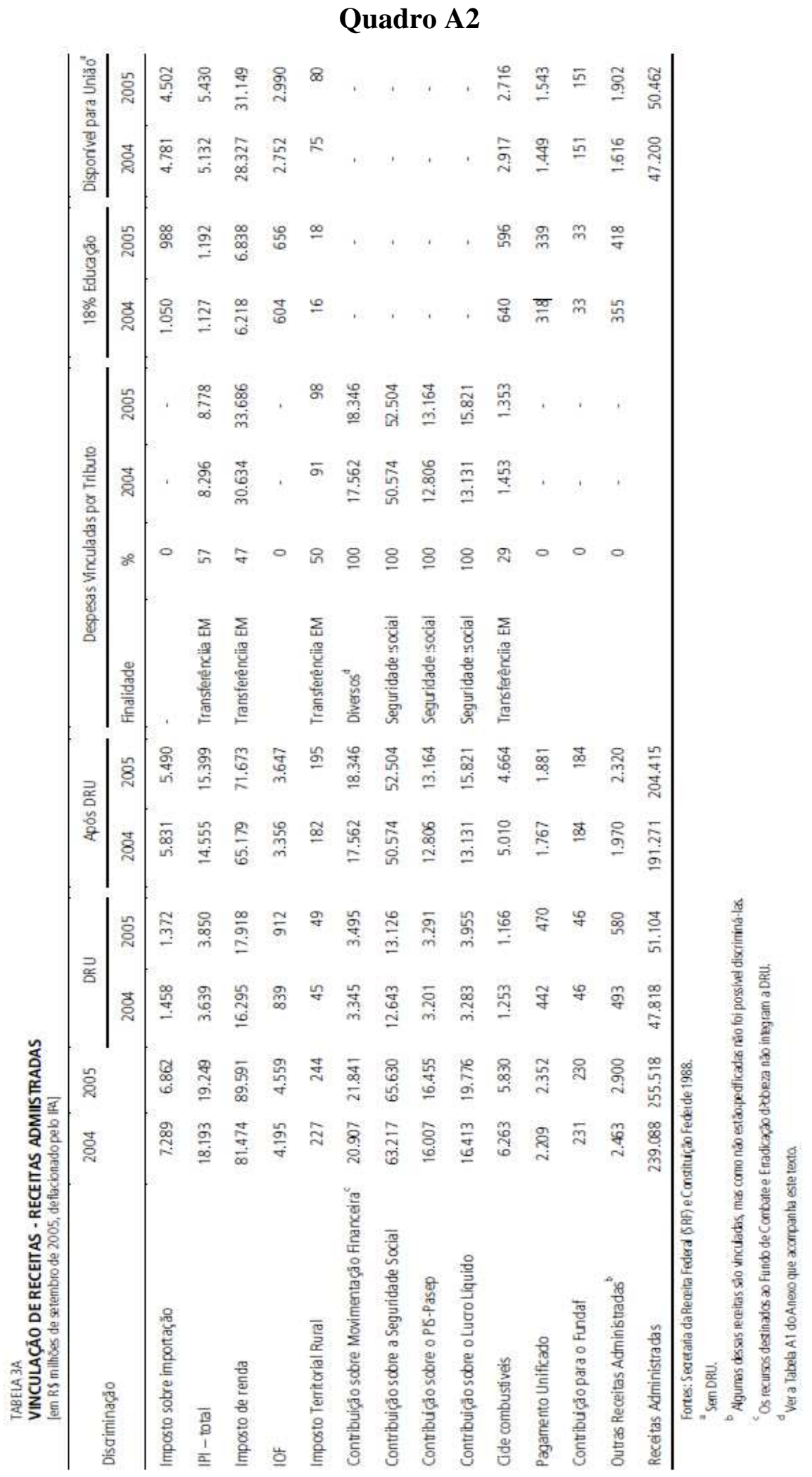




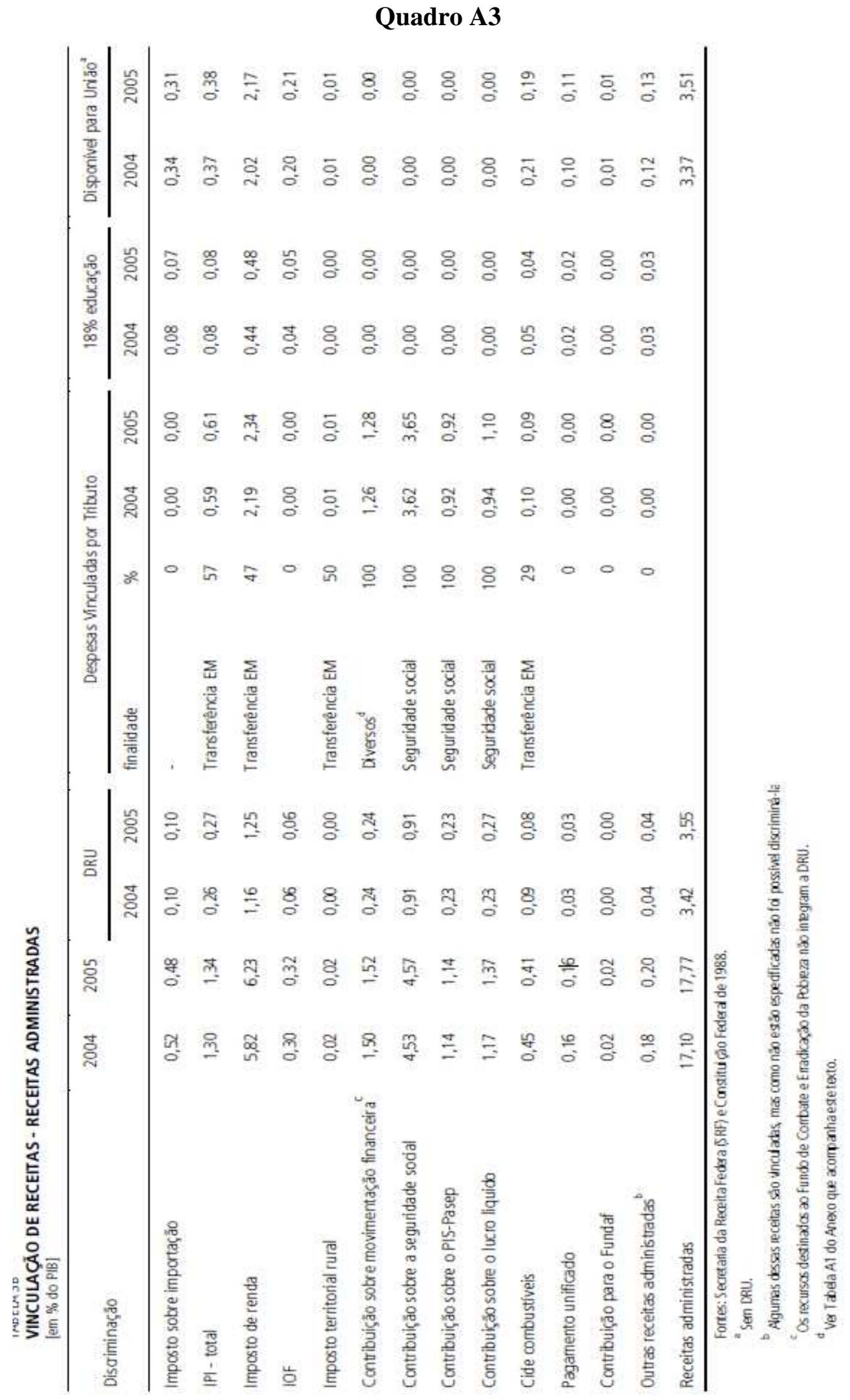




\section{Quadro A4}

\section{DESVINCULAÇĀO DE RECURSOS DA UNIĀO}

\begin{tabular}{|c|c|}
\hline Desvinculação de recursos da União & PLO 2006 \\
\hline 1. Total das receitas & 493.326 .773 .190 \\
\hline 1. Receita de impostos - Art $2^{\circ}$ da PEC $41 / 2003$ & 161.295 .063 .676 \\
\hline L1.1. Principal & 158.012 .081 .370 \\
\hline 1.1.2. Multas, juros e divida ativa & 2.121 .801 .803 \\
\hline I.1.3. Refis & 1.161 .180 .503 \\
\hline 2. Receita de contribuiçōes sociais - Art. $2^{\circ}$ da PEC 41/2003 & 320.324 .437 .635 \\
\hline 1.2.1. Principal & 314.929 .740 .013 \\
\hline 1.2.2. Multas, juros e divida ativa & 3.615 .479 .719 \\
\hline 1.2.3. Refis & 1.779 .217 .903 \\
\hline 3. Receita de contribuiçôes econômicas - Art. $2^{\circ}$ da PEC $41 / 2003$ & 11.707 .271 .879 \\
\hline 1.3.1. Principal & 11.706.901.901 \\
\hline 1.3.2. Multas, juros e divida ativa & 369.978 \\
\hline 11. Exclusōes & 146.256 .467 .771 \\
\hline Il.1. Contribuiç̧ōes sociais & 146.256 .467 .771 \\
\hline 11.1.1. INSS (Fontes 154 e 954) - Art. 58, parágrafo $2^{\circ}$ da Lei $n^{\circ} 10.707 / 2003$ - LDO/04 & 120.312 .557 .435 \\
\hline IL1.2. Salário educaçäo (Fonte 113) - Art. 76, parágrafo $2^{\circ}$ do ADCT & 7.183.099.975 \\
\hline 1L1.3. CPMF - Fundo de Combate à Pobreza - Art 80, parágrafo $1^{\circ}$ do ADCT & 6.755 .041 .675 \\
\hline 11.1.4. CPSS - Contribuiçăo Plano de Seguridade Social dos Servidores Públicos & 12.005 .768 .686 \\
\hline \multicolumn{2}{|l|}{ 11.2. Compensaçôes financeiras } \\
\hline \multicolumn{2}{|l|}{ 11.2.1. Utilizaçâo de recursos hidricos } \\
\hline \multicolumn{2}{|l|}{ 11.2.2. Exploraçāo de recursos minerais } \\
\hline \multicolumn{2}{|l|}{ 11.2.3. Royalties produçāo em terra } \\
\hline \multicolumn{2}{|l|}{ 11.2.4. Royalties produçāo em plataforma } \\
\hline \multicolumn{2}{|l|}{ 11.2.5. Royalties excedentes produç̧0 em terra } \\
\hline \multicolumn{2}{|l|}{ 11.2.6. Royalties excedentes produçâo em plataforma } \\
\hline \multicolumn{2}{|l|}{ II.2.7. Participaçāo es pecial produçāo petróleo } \\
\hline 11I. Base de cálculo DRU (1-11) & 347.070 .305 .419 \\
\hline IV. DRU $\left(||{ }^{*} 20 \%\right)$ & 69.414 .061 .084 \\
\hline IV.1. Impostos $[(1.1) * 20 \%]$ & 32.259 .012 .735 \\
\hline IV.2. Contribuiç̄es sociais [( $\left.1.2-11.1)^{*} 20 \%\right]$ & 34.813 .593 .973 \\
\hline IV.3. Contribuiç̧ôes econômicas $[(1.3-\| 1.2) * 20 \%]$ & 2.341 .454 .376 \\
\hline
\end{tabular}
Fonte: Anewo XV do Projeto de Lei Orcamentária. 
Quadro A5

RESULTADO PRIMARIO DO GOVERNO CENTRAL - DESPESAS - ACUMULADO JAN.SET. 2004 A 2005

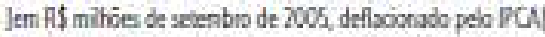

\begin{tabular}{|c|c|c|}
\hline & 2,004 & 2.005 \\
\hline Despesa prinarla & 283.604 & 304.805 \\
\hline L. Transferêndas a estados e minildpios & 53.930 & 61.394 \\
\hline 1.1. Trassfeetenda constituconats (if, IR e outras) & 41.350 & 46.596 \\
\hline 1.2. Lei Complementar 87i Fundo de Compensaça de Exportaçoes & 3.516 & 3.290 \\
\hline 1.3. Trandetetndas da Odz & 738 & 1.383 \\
\hline 14. Demaks & 8.326 & 10.125 \\
\hline I. Pessoal e encargos sodais & 67.246 & 65.060 \\
\hline A. Beneliclos previdencarios & 93307 & 101.746 \\
\hline N. Custeio e Captal & 67.551 & 74.875 \\
\hline IV.1. Despesa do FAT & 7.841 & 8.841 \\
\hline - Abono e seguro desenprego & 7.546 & 1,985 \\
\hline - Denals despesas do FAT & 295 & 57 \\
\hline IV.2. Subsidias e subvençues economicas & 3.034 & 2.461 \\
\hline - Operaçoes oficlas de ctedito & 2.048 & $=$ \\
\hline - Subvençles aos tundos regionals & 985 & - \\
\hline N.3. LoasRMV & 5.979 & 6,860 \\
\hline IV.4. Outas despesas de custeco e capital. & 50.697 & 53.972 \\
\hline Despesas discricondelizs: & 23.081 & 25.725 \\
\hline Despesas ressativadas: & 27.616 & 28.247 \\
\hline Sacde" & 23.159 & 23.291 \\
\hline Finandados pela CPMF. & 8.802 & 9.195 \\
\hline Finandados por outros & 14.357 & 14.086 \\
\hline Fundo de contate a potreza' & 4.457 & 4.956 \\
\hline Finandados pela CPMF & 4.411 & 4.608 \\
\hline Finandados por cuttos & 45 & 349 \\
\hline IV.4. Transferencla do Tescuro ao Banco Central & 471 & 456 \\
\hline N5. Despesas do Banco Central & 1.098 & 1.323 \\
\hline Despesas nao-disticionarias & $82,12 \%$ & $81,41 \%$ \\
\hline Despesas ressayvadas & $9,74 \%$ & $9,27 \%$ \\
\hline Despesas discoticlonarias & $8,14 \%$ & $B, 44 \%$ \\
\hline
\end{tabular}

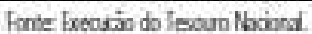




\section{REFERÊNCIAS}

ALBUQUERQUE, C.; MEDEIROS, M.; FEIJÓ, P.H.; Gestão de finanças públicas: Fundamentos e Práticas de Planejamento, Orçamento e Administração Financeira com responsabilidade Fiscal. $1^{\mathrm{a}}$ ed. Brasília, DF. Editora Cidade, 2006.

AZEVEDO, B.M. O processo orçamentário brasileiro pós 1994. Dissertação (Mestrado em Economia) - Departamento de Economia da Universidade de Brasília - UNB, Brasília, p. 120-157, nov. 2006.

BRASIL. Vinculações de receitas dos orçamentos fiscal e da seguridade social e o poder discricionário de alocação de recursos do governo federal. Ministério do Planejamento, Orçamento e Gestão, vol 1, n. 1. Brasília: fev. 2003.

GIACOMONI, J. Orçamento Público. 13a. ed. São Paulo: Atlas, p.199-203, 2005.

GOLDFAJN, I. Há razões para duvidar de que a dívida pública no Brasil é sustentável? Notas Técnicas do Banco Central do Brasil. n. 25, p. 10-26, jul. 2002.

SUZUKI JÚNIOR, J.T. Política fiscal: resultados e perspectivas. Análise Conjuntural, v.25, n.910, p.14-15, set./out. 2003

MENDES, M. J. Sistema orçamentário brasileiro: planejamento, equilíbrio fiscal e qualidade do gasto público. Consultoria Legislativa do Senado Federal - Estudo, jan. 2008.

MORA, M. A Proposta de déficit nominal zero e o gasto discricionário no governo federal. Boletim de Conjuntura. IPEA. p.99-107, dez. 2005.

PIRES JÚNIOR, J. A. M. A realização orçamentária e financeira de emendas orçamentárias e o seu controle pelo executivo por meio da (IN)Fidelidade Parlamentar. Monografia. Portal da secretaria do tesouro nacional, 2009.

Disponível em:

http://www.tesouro.fazenda.gov.br/premio_tn/xpremio/sistemas/1tosixptn/1premio_tosi.pdf Acesso em: 02 fev, 2009.

PIRES, M. C. C. Credibilidade na política fiscal: uma análise preliminar para o Brasil. Economia Aplicada, São Paulo, v. 10, n. 3, p. 373-377, 2006.

SAMUELS, D. A economia política da reforma macroeconômica no Brasil, 1995-2002. DADOSRevista de Ciências Sociais, Rio de Janeiro, vol.46, no.4, pp.805-835, 2002.

STN. Glossário. Portal da secretaria do tesouro nacional, 2009.

Disponível em:

http://www.tesouro.fazenda.gov.br/servicos/glossario/glossario_a.asp

Acesso em: 02 fev, 2009.

. Lei de responsabilidade fiscal comentada. Portal da secretaria do tesouro nacional, 2009.

Disponível em: 
http://www.tesouro.fazenda.gov.br/hp/lei_responsabilidade_fiscal.asp Acesso em: 31 jan, 2009.

Plano Anual de Financiamento. Portal da secretaria do tesouro nacional, 2009.

Disponível em:

http://www.tesouro.fazenda.gov.br/hp/downloads/PAF_Proposta_Divulgacao270808.pdf http://www.tesouro.fazenda.gov.br/divida_publica/downloads/Apresentacao_Relatorio_Divida_200 8.pdf http://www.tesouro.fazenda.gov.br/hp/downloads/PAF_2007.pdf http://www.tesouro.fazenda.gov.br/hp/downloads/resultado/PAF_2006.pdf http://www.tesouro.fazenda.gov.br/hp/downloads/resultado/paf_2005.pdf http://www.tesouro.fazenda.gov.br/hp/downloads/resultado/paf_2004.pdf http://www.tesouro.fazenda.gov.br/hp/downloads/resultado/paf2003.pdf http://www.tesouro.fazenda.gov.br/hp/downloads/resultado/paf2002.pdf http://www.tesouro.fazenda.gov.br/hp/downloads/resultado/paf2001.pdf Acesso em: 03mar, 2009. 